Journal of Social Sciences (COES\&RJ-JSS)

ISSN (E): 2305-9249 ISSN (P): 2305-9494

Publisher: Centre of Excellence for Scientific \& Research Journalism, COES\&RJ LLC

Online Publication Date: $1^{\text {st }}$ January 2019

Online Issue: Volume 8, Number 1, January 2019

https://doi.org/10.25255/jss.2019.8.1.106.138

\title{
Strategic Leadership Competencies and its Impact on Achieving Organizational Excellence via the Mediating Role of Organizational Commitment: A Case Study in National Center for Security and Crisis Management (NCSCM)
}

\author{
Adnan Ahmad Olwan \\ Vice President of National Center for Security and Crisis Management, Amman, Jordan, \\ aolwan@gmail.com \\ Hani Jaza'a Irtaimeh \\ Dean of the Faculty of Business \& Finance, The World Islamic Sciences and Education \\ University, Amman, Jordan, drhaniirtaimeh@yahoo.com \\ Musa Al-Lozi \\ Department of Public Administration, School of Business, The University of Jordan, \\ Amman, Jordan \& President of Aqaba Branch, The University of Jordan, Aqaba, \\ Lozi.musa@ju.edu.jo
}

\begin{abstract}
:
This study aimed at revealing the reality of the implementation of strategic leadership, in addition to test the relationship of cause and effect between strategic leadership and organizational excellence through the intermediate role of organizational commitment. The National Center for Security and Crisis Management was chosen as a targeted population of the current study; as an organization that has a big responsibility for practicing strategic leadership which is closely related to the workers of the Center. The study followed the analytical descriptive method by reviewing the theoretical literature and previous studies related to the current study variables. The questionnaire was used as a tool for collecting data from the members of the study population in the center which consisted of 160 members. The questionnaire consisted of (25) items for measuring strategic leadership, (27) items for measuring organizational excellence, and (9) items for measuring the organizational commitment, and the validity and reliability were verified. Arithmetical averages, standard deviations, simple regression coefficient, and multiple regression coefficients were used to test the hypotheses of the study and answer its questions. The results of the study showed a high level of strategic leadership as well as organizational excellence and organizational commitment. There was a significant impact of strategic leadership and organizational commitment on organizational excellence at the significance level of ( $\alpha \leq 0.05)$, and a significant impact of the intermediate factor at the significance level of $(\alpha \leq 0.05)$. One of the main recommendations of the study for the National Center for Security and Crisis Management was "to identify future opportunities based on information from various sources".
\end{abstract}

\section{Keywords:}

Strategic Leadership, Organizational Excellence, Organizational Commitment, National Center for Security and Crisis Management

This work is licensed under a Creative Commons Attribution 4.0 International License. 


\section{Citation}

Olwan, Adnan Ahmad; Irtaimeh, Hani Jaza'a; Al-Lozi, Musa (2019); Strategic Leadership Competencies and its Impact on Achieving Organizational Excellence via the Mediating Role of Organizational Commitment: A Case Study in National Center for Security and Crisis Management (NCSCM); Journal of Social Sciences (COES\&RJ-JSS), Vol.8, No.1, pp:106-138; https://doi.org/10.25255/jss.2019.8.1.106.138.

\section{جدارات القيادة الاستراتيجية وأثرها في تحقيق التميز المنظم من خلال الدور الوسيط للإلتزام المنظمي: دراسة

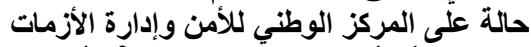

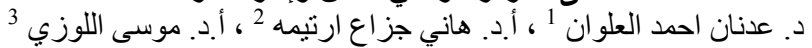

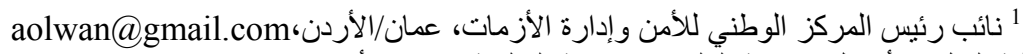

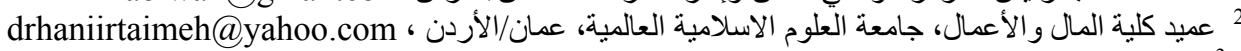
$3{ }^{3}{ }^{3}$

\section{الملخص}

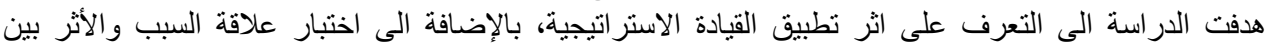

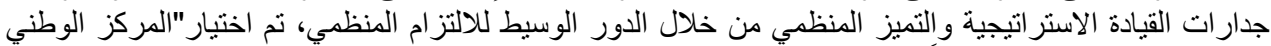

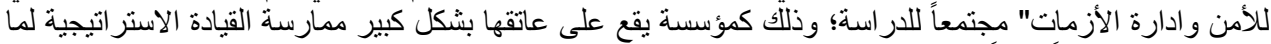

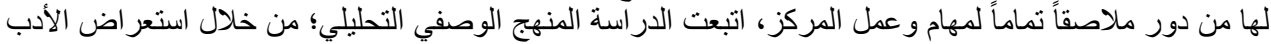

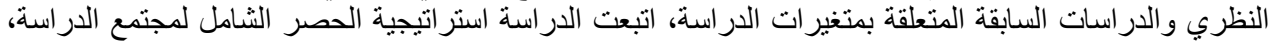

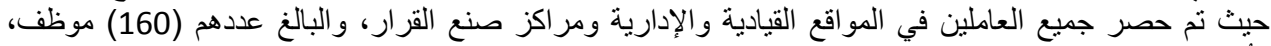

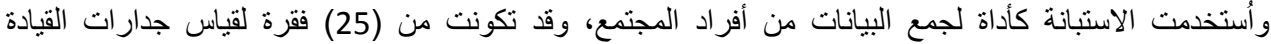

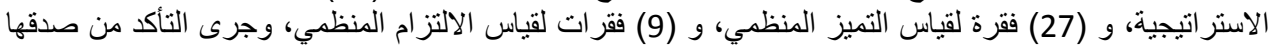

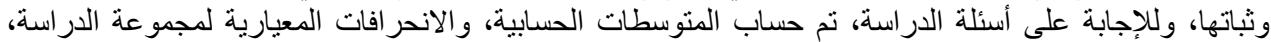

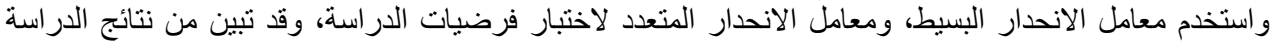

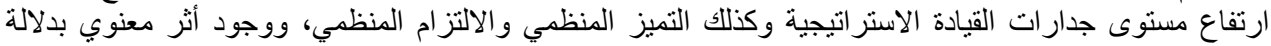

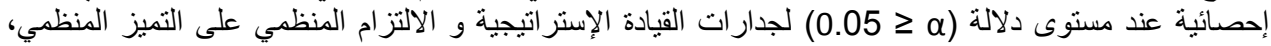

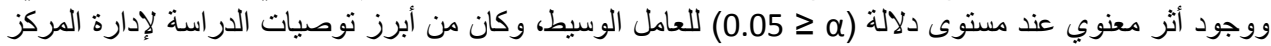

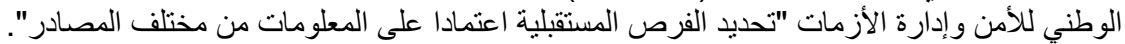

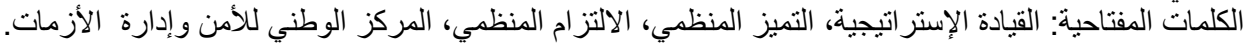

إن التميز المنظمي الذي تصبو إليه المنظمة لا يتحقق الا من خلال مجموعة من الأبعاد و التي لا بد للمنظمة من تحقيقها

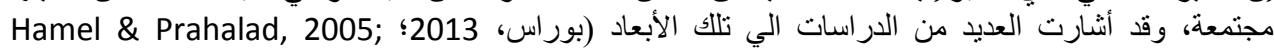

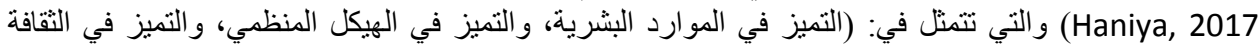

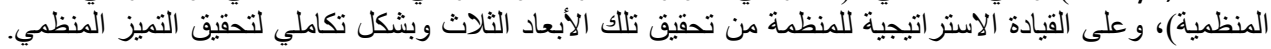

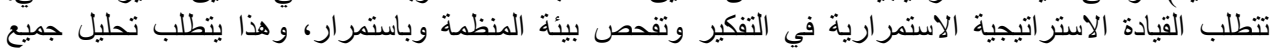

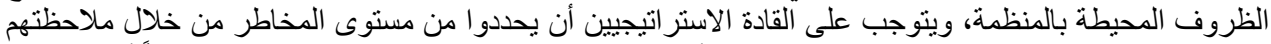

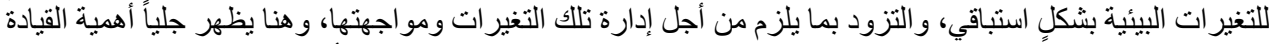

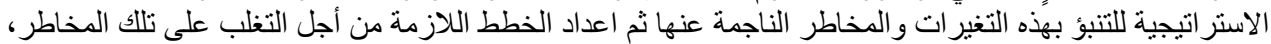

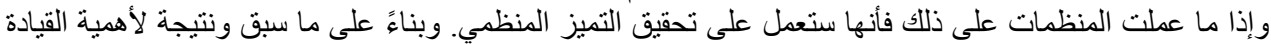

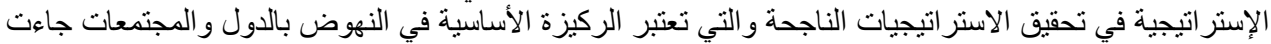

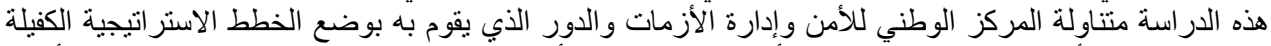

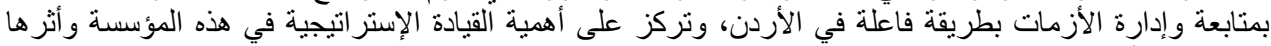

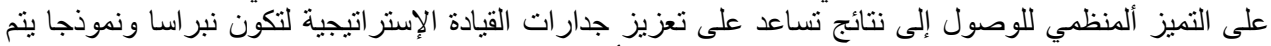

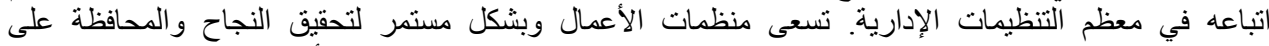

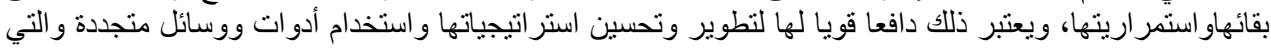




\section{Strategic Leadership Competencies and its Impact ....}

تمكنها من رفع أدائها و انتهاز الفرص الجديدة والتغلب على التحديات الذي يضمن لها تحقيق التقام والتطور المستمر على مستوى المنتجات و الخدمات.

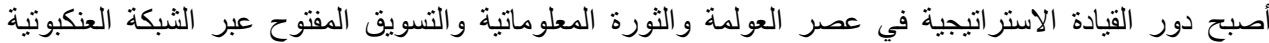

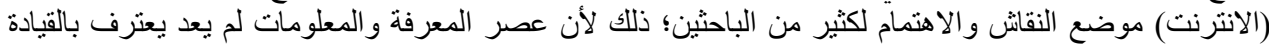

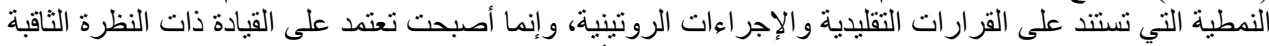

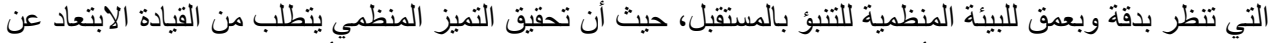

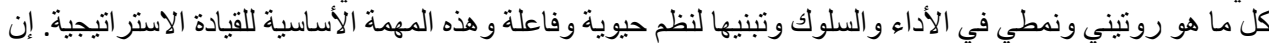

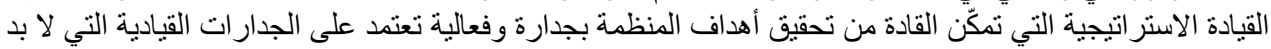

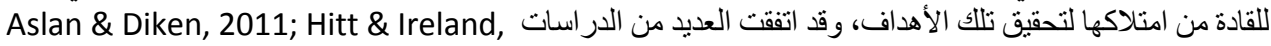

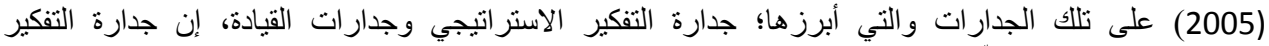

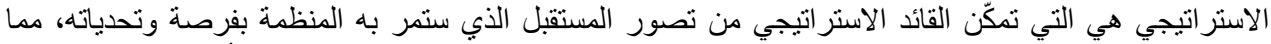

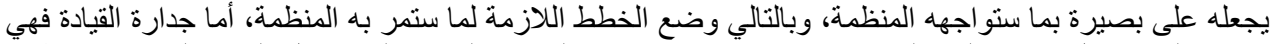
تعتمد على عوامل عدة تتعلق بالقائد نفسة، وهي مجموعة وبلى من السمات القيادية التي تؤهل هل القائد على إدارة منظمته

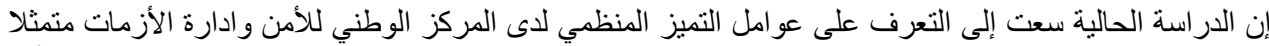

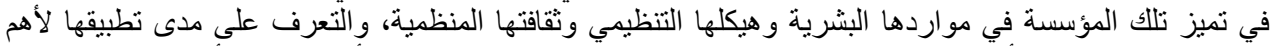

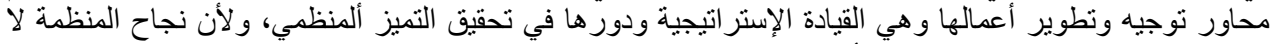

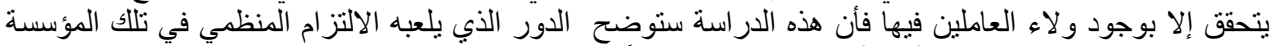

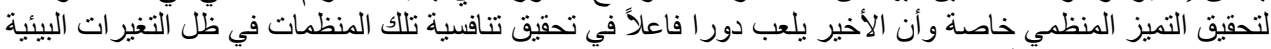

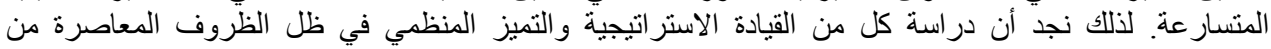

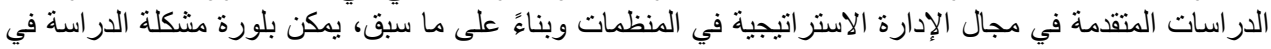

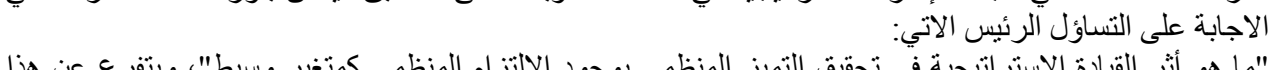
"ما هو أثر القيادة الاستراتيجية في تحقيق التميز المنظمي بوجود الالتنزام المنظمي كمتغير وسيط"، ويتفرع عن هذا

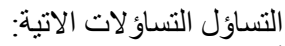
أو لا: ما هو و اقع ممارسة القيادة الاستراتيجية ـ منمثلا في بعديها: جدارات التفكير الاستر اتيجي، وجدارات القيادة- في

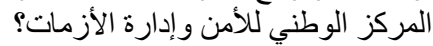

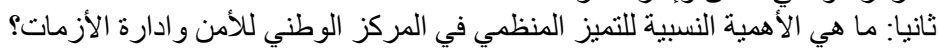

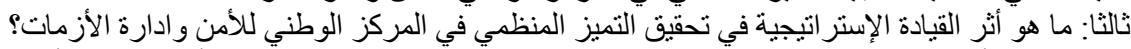

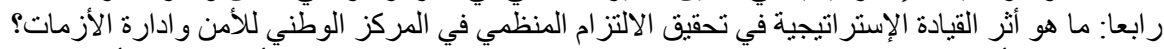

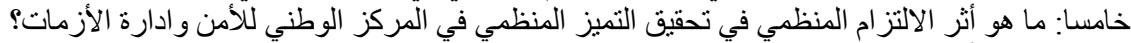

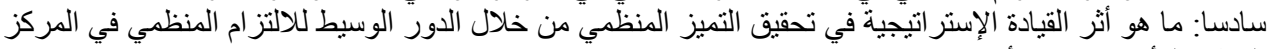

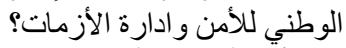

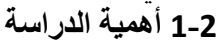

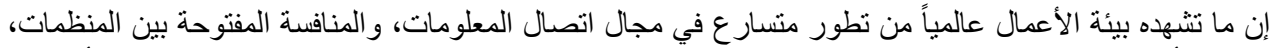

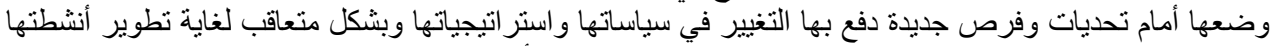

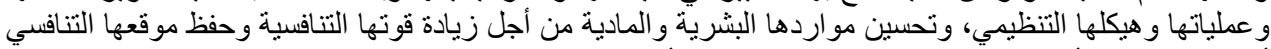

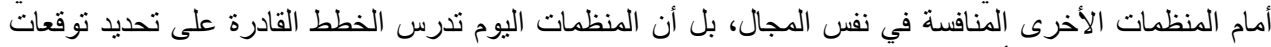

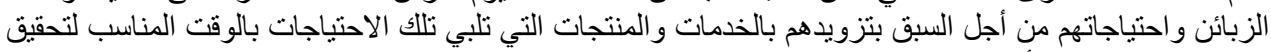

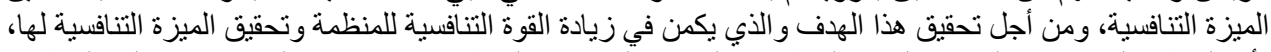

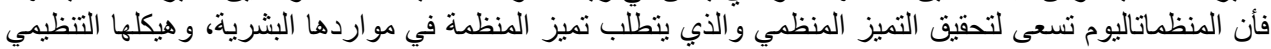

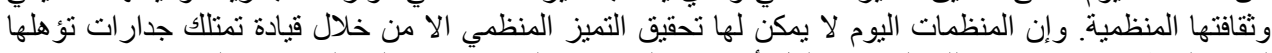

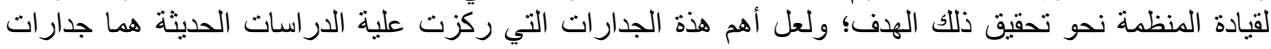

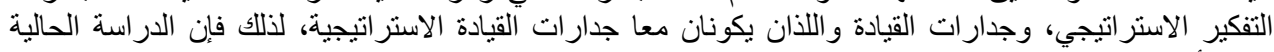

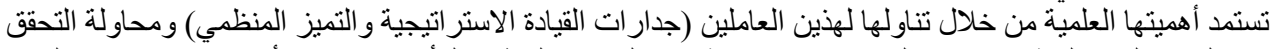

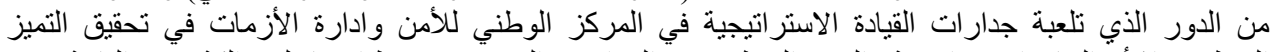

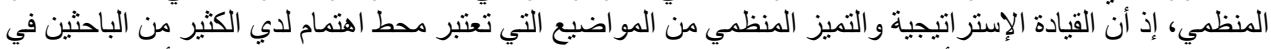

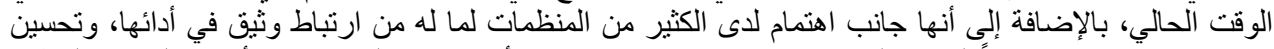

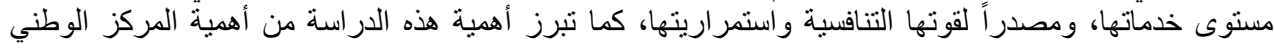




\section{Journal of Social Sciences (COES\&RJ-JSS), 8(1), pp.106-138}

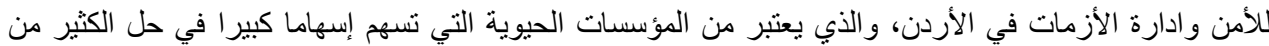

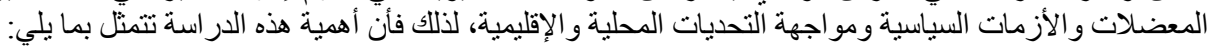

أولا: الأهمية العمية/ النظرية العزية

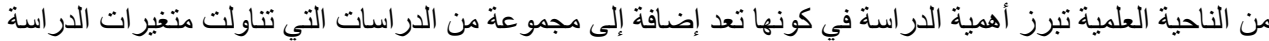

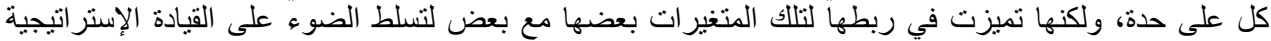

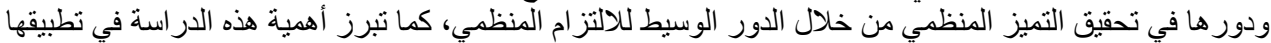
على أحد أبرز المؤسسات الوطنية الونية الا و هو المركز الوطني الوني للأمن و إدارة الأزمات. ثنانيا: الأهمية التطبيقية، و التي تتمثل في: الإني

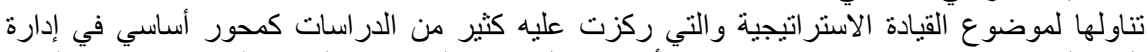

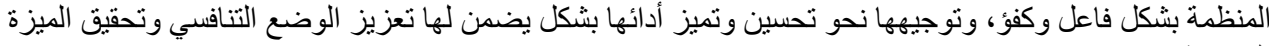

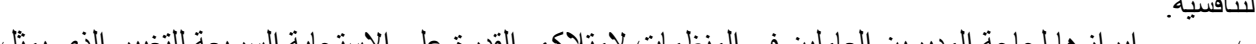

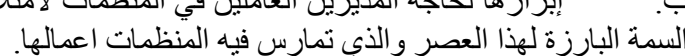
1-3 أهداف الاراسة البارة التعرف إلى أثر جدارات القيادة الإستراتيجية وجدارتها في المركز الوطني للأمن وادارة الأزمات وأثرها تهذف هذه الدراسة إلى الاتي:

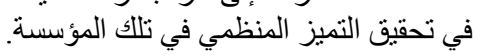
التعرف إلى المضامين الفكرية والنظرية لكل من متغيرات الدراسة ( القيادة الإستراتيجية، الالتزام

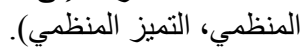

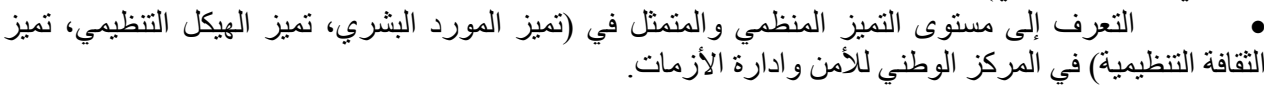

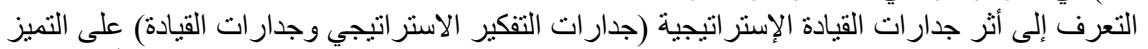

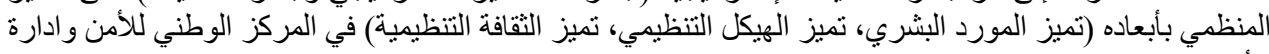

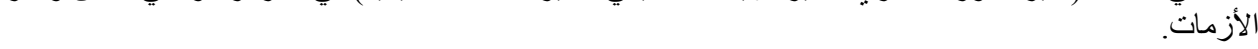
التعرف إلى دور الالتزام المنظمي (الالتزام العاطفي، الالتزام الأخلاقي، و الالتزام المستمر) في التميز تقديم مجموعة من التوصيات بناءً على النتائج التي توصلت إليها التيا الدراسة قد تساعدُ في تعزيز التمبز

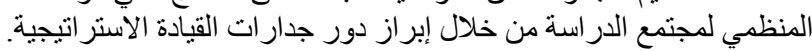

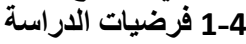
انطلاقا من مشكلة الدر اسة و التساؤلات فقد تم صياغة الفرضيات الصفرية التالية:

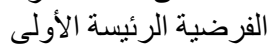

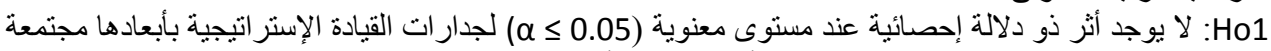
في تحقيق التميز المنظمي في المركز الونئ الوطني للأمن و ادارة الأزمات وينبثق عنها الفرضيات الفرعية التالية:

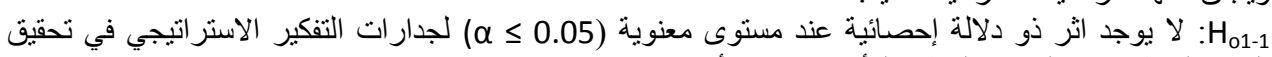

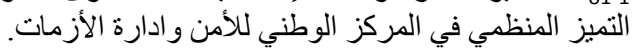

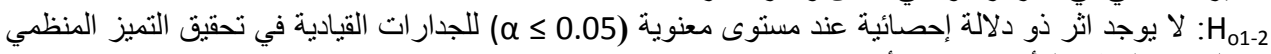
في المركز الوطني للأمن و ادارة الأزمات.

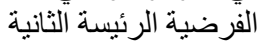

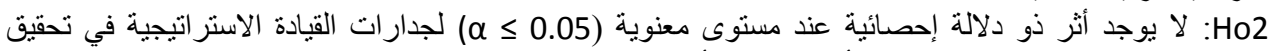

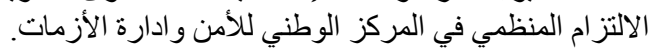
وينبثق عنها الفرضيات الفرعية التالية:.

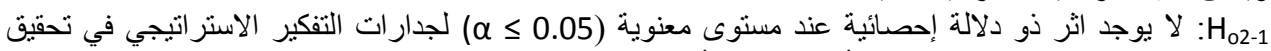

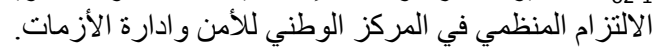

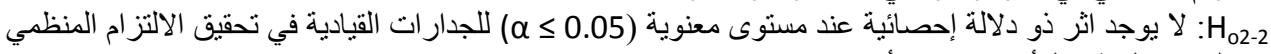
في المركز الوطني للأمن وادارة الأزمات. 
الفرضية الرئيسة الثالثة

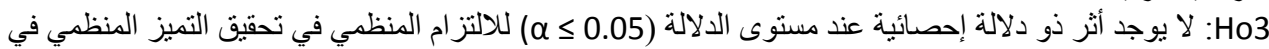
المركز الوطني للأمن و ادارة الأزمات.

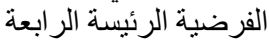

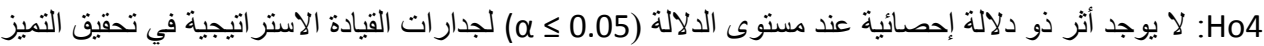

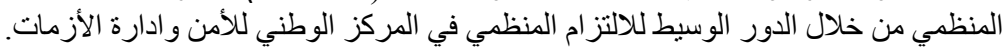

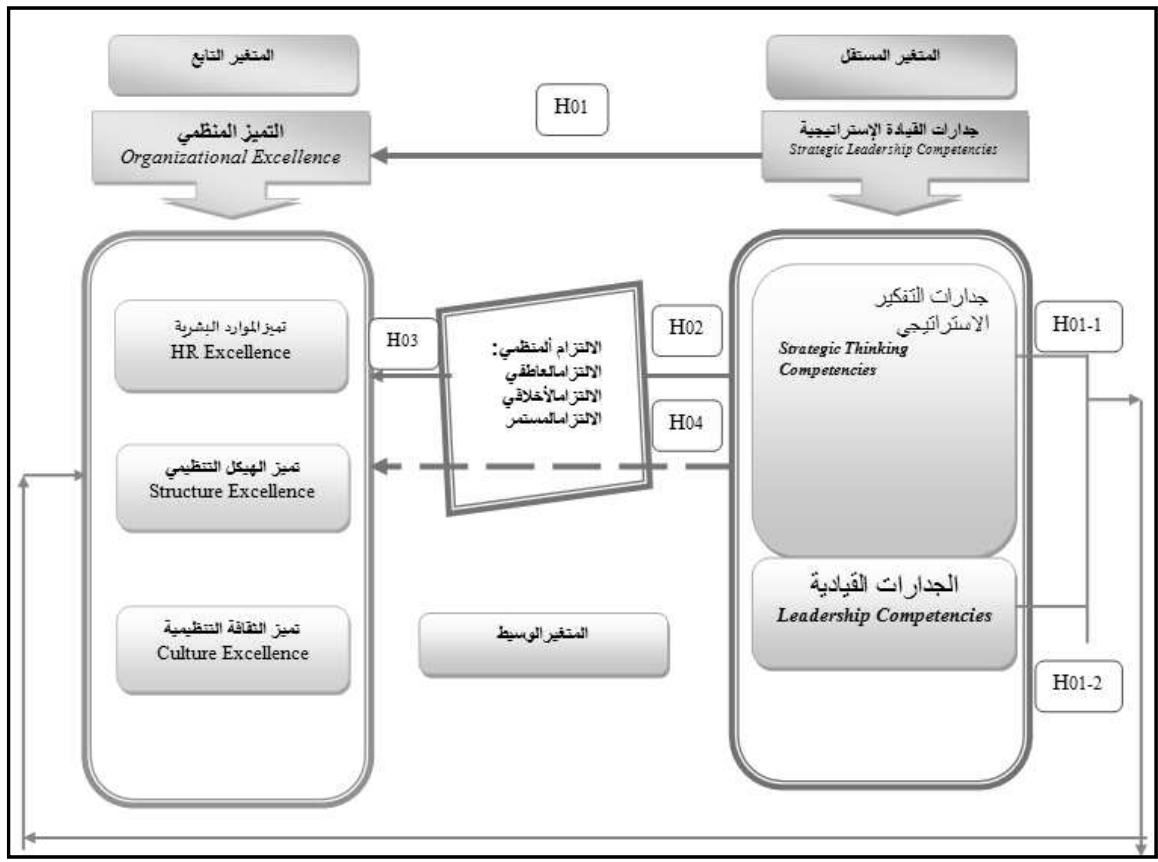

الثكل رقم (1) ـ أنموذج الدراسة و المصدر : من إعداد الباحث بالاعتماد على الدراسات السابقة.

جدول (1). مصادر متغيرات الدراسة

\begin{tabular}{|c|c|c|c|}
\hline در اسات سابقة & المتغير الفرعي & المتغير الرئيسي & نوع المتغير \\
\hline $\begin{array}{r}\text { Azbari et al.(2015); Irtaimeh (2017); } \\
\text { Nuntamanop et al. (2013) }\end{array}$ & جدارات التفكير & \multirow[t]{2}{*}{ الاستر اتيجية القيادة } & \multirow[t]{2}{*}{ ال - المتنقل } \\
\hline $\begin{array}{r}\text { Turner \&Clark \& Armit (2010); Müller } \\
\text { (2009) المبيضين(2010); }\end{array}$ & جدار ات القبادة & & \\
\hline Wright et al. (2000); جروة و خيرة (2014); & التميز في الموارد & \multirow[t]{3}{*}{ التميز المنظمي } & \multirow[t]{3}{*}{ 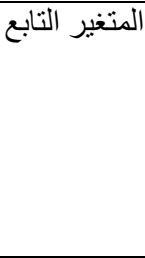 } \\
\hline $\begin{array}{r}\text { Chen \& Huang (2007); Haniya(2017); León } \\
\text { \& Martínez (2011) }\end{array}$ & التميز في الهيكل & & \\
\hline $\begin{array}{l}\text { Hamel \& بور اس (2013)؛ الحسن (2005) (2005) } \\
\text { Prahalad }\end{array}$ & التميز في الثقافة المنظمية & & \\
\hline $\begin{array}{r}\text { Mills \& Ungson ( 2003); Rahman et al. } \\
\text { \& (2015); Spreitzer (2007); Tutuncu } \\
\text { (2016) الحيانKucukusta (2007 }\end{array}$ & & الالتز ام المنظمي & 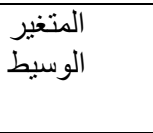 \\
\hline
\end{tabular}




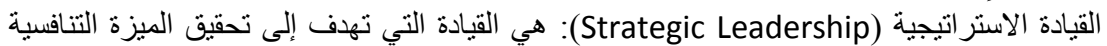

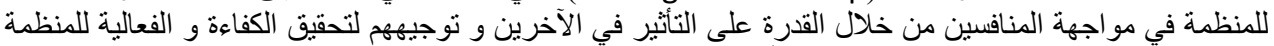

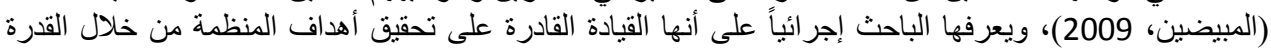

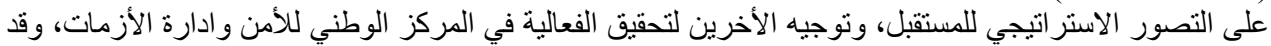

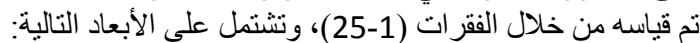

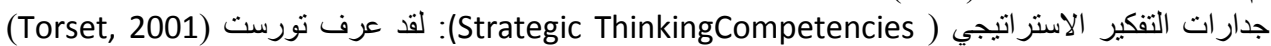

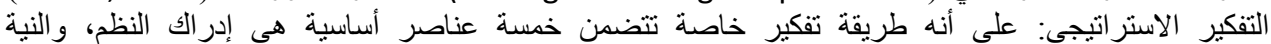

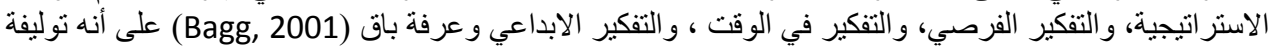

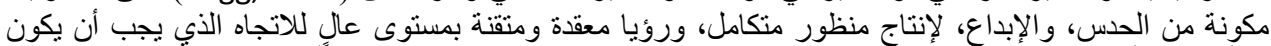

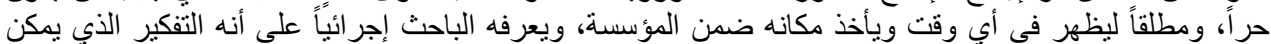

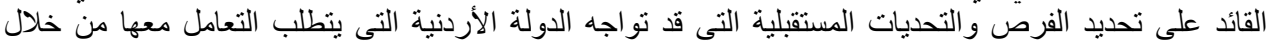

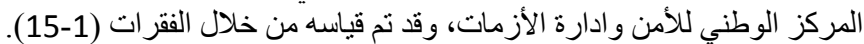

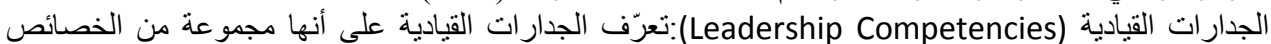

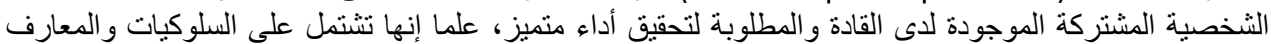

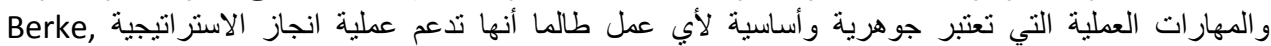

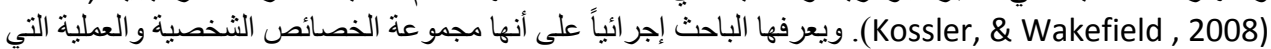

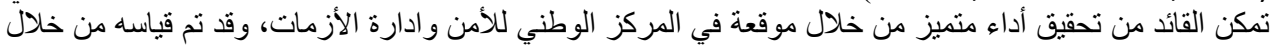

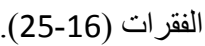

ب. ب التمات (25inar \& Girard, 2008) التميز المنظمي بأنه استثمار

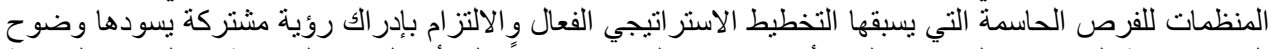

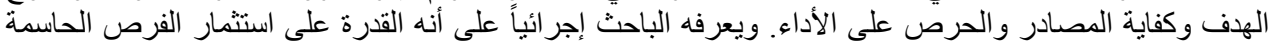

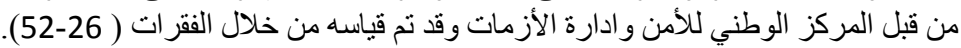

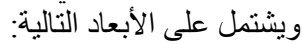

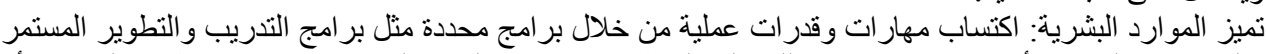

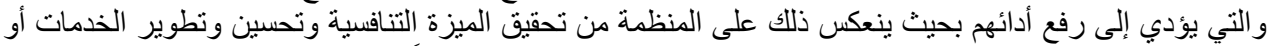

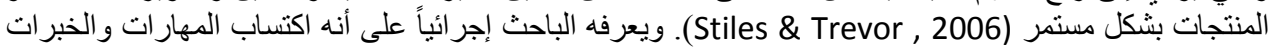

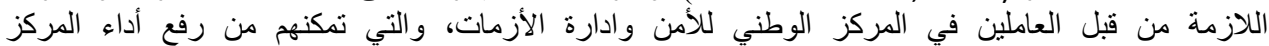

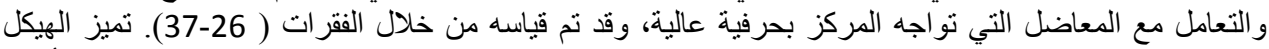

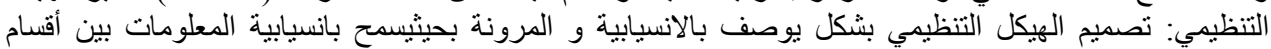

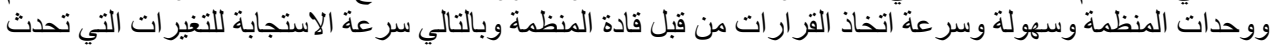

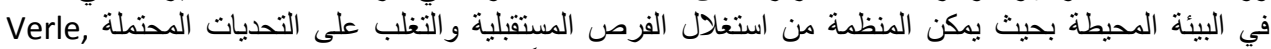
Markič, Kodrič, \& Zoran, 2014

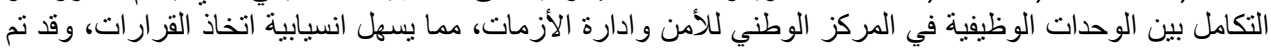

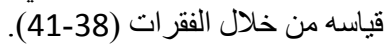

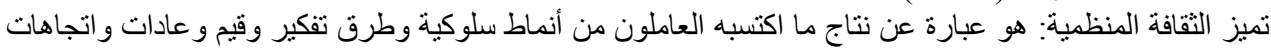

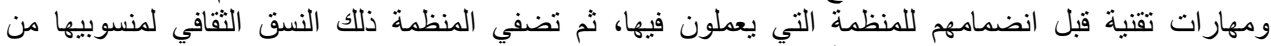

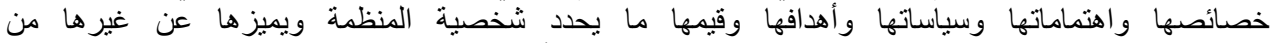
المنظمات(Qawasmeh, Darqal, 2013). ويعرفه الباحث على أنه مجمو عة القيم و العادات و السياسات و الاتجاهات التفكير

وطرق

التي يتسم بها العاملون في المركز الوطني للأمن و ادارة الأزمات، وقد تم قياسه من خلال الفقرات (42-52).

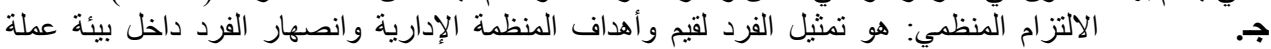

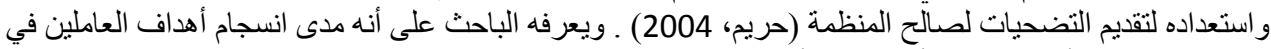

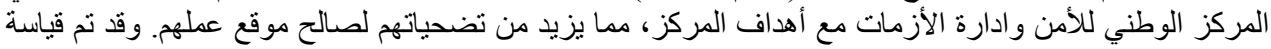

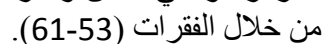
1-7 حدود الاراسة الحدود المكانية: تم تطبيق الدراسة على المركز الوطني للأمن و ادارة الأزمات.

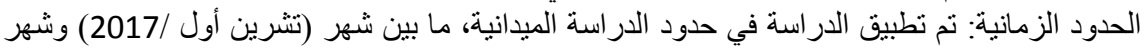
(كانون ثاني / 2017) للعام الدر اسي (2017-2018 ) . 


\section{Strategic Leadership Competencies and its Impact ....}

الحدود البشرية: تم تطبيق الدراسة على كافة القيادات و العاملين في المركز الوطني للأمن وادارة

1-8 ما يميز الاراسة الحالية

تتميز هذه الدراسة عن الدر اسات السابقة من حيث:

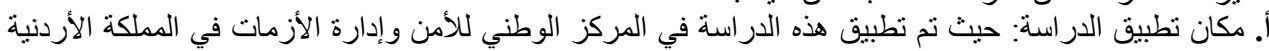

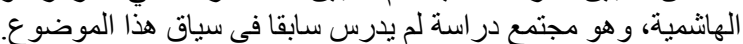

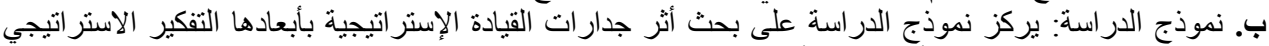

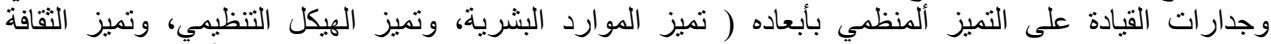

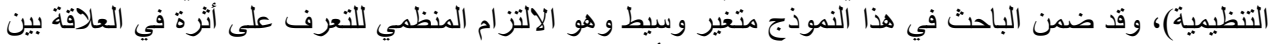

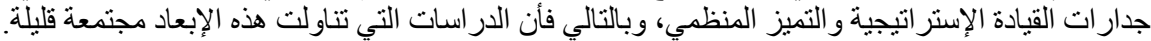

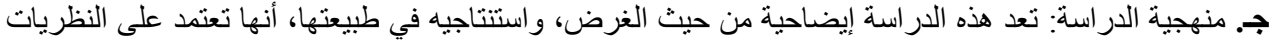

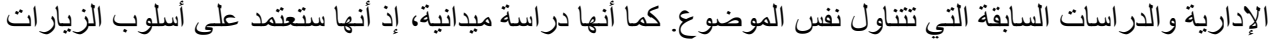

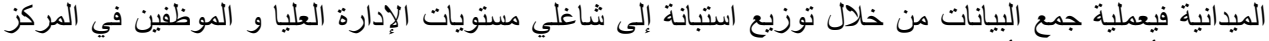

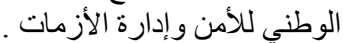

2. منهجية الدراسة (الطرق والاجراء الأات)

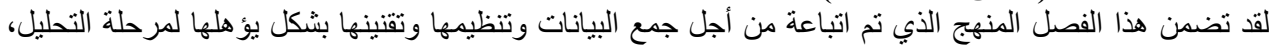

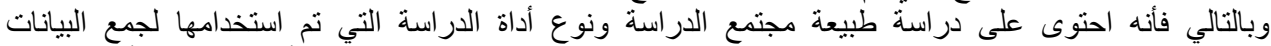
و الإجراءات التي تم استخدامها لتصميم الاستبانة والعمليات الإحصائية التحنية التي استخدمت للنأكد من صدق أداة الدراسة

وثباتها.

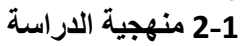

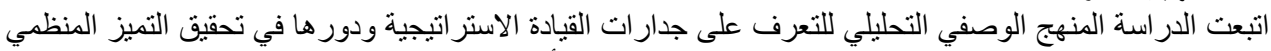

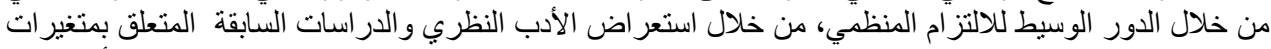

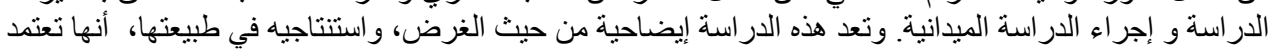

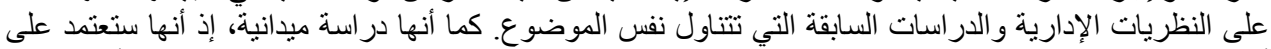

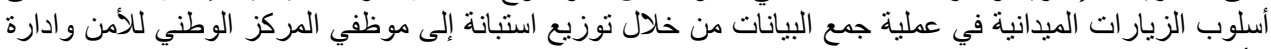

2-2 2-2 استراتيجية الاراسة

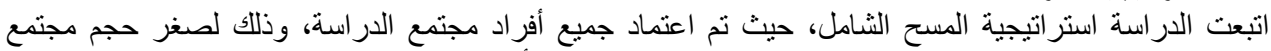

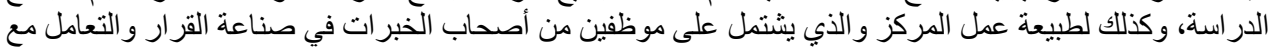
الأزمات على مستوى الدولة.

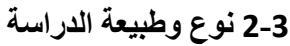

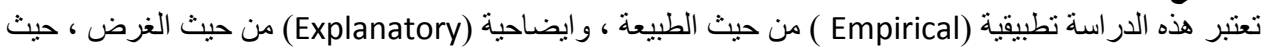

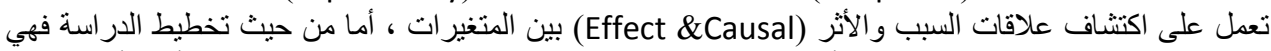

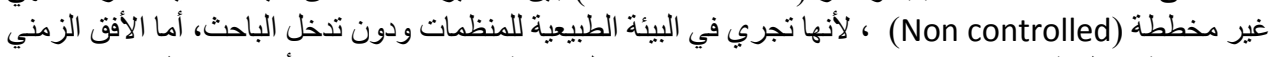

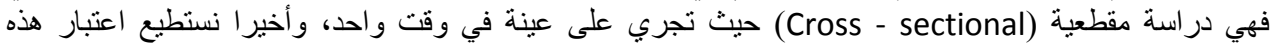

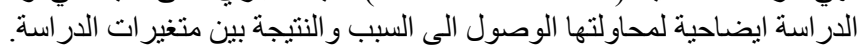

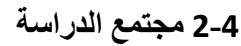

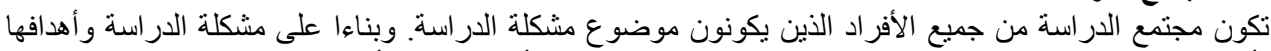

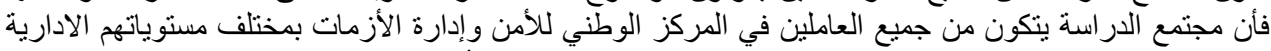

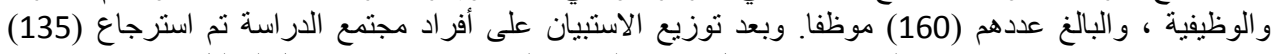

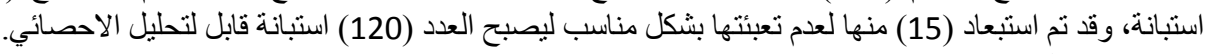
2-5 مصادر البيانات

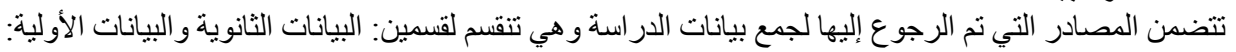

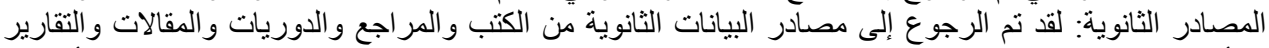

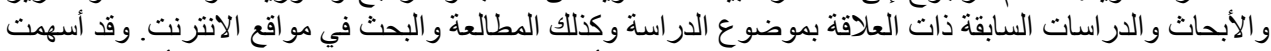

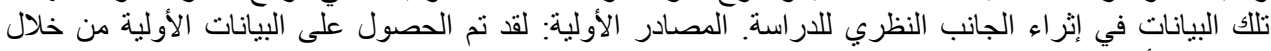

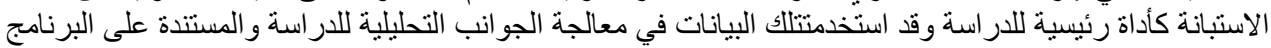

الإحصائي. 
2-6 خطوات تصميم بناء الاستبانة

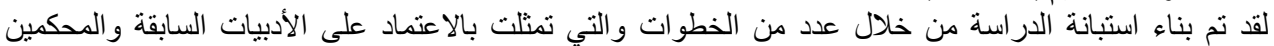
الأكاديميين وذللك من خلال الخطو اتل اتلات الآتية:

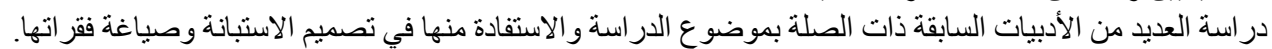

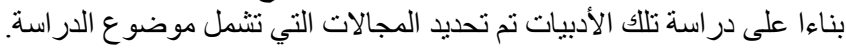

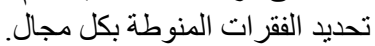

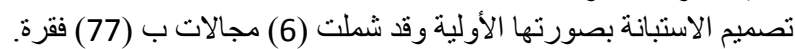

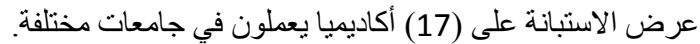

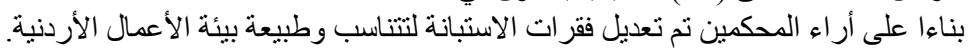

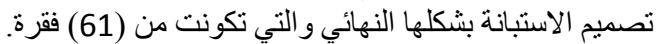
2-7 أداة الاراسة

لقد تم إعداد أداة الدر اسة بحيث تكونت من قسمين رئيسين:

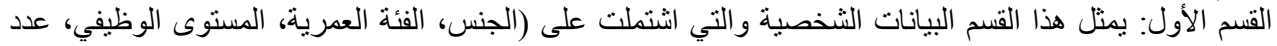

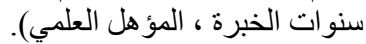
القسم الثاني: انتمل هذا القسم على مجالات الاستبانة (6 مجالات) ممثلة ب (61) فقرة. و هذه المجالات تثمل: المجال الأول: جدار ات التفكير هذات الاستر اتيجي (15فقرة). المجال الثاني: جدار ات القياد التيادة (10فقرات).

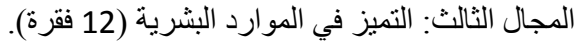

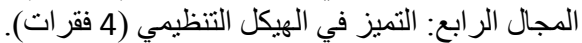
المجال الخامس: التميز في الثقافة التنظيمية (111فقرة). المجال السادس: الالتز ام ألمنظمي (9 فقرات).

\begin{tabular}{|c|c|c|c|c|c|}
\hline مو افق بشدة & مو افق & محايد & غير مو افق & غير موافق بشدة & الاستجابة \\
\hline 5 & 4 & 3 & 2 & 1 & الدرجة \\
\hline
\end{tabular}

ولقياس درجة استجابة المبحوثين لفقرات الاستبيان تم استخدام مقياس ليكرت الخماسي و الذي تراوح ما بئ بين (1) التي

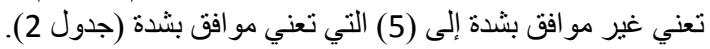
جدول (3). معيار الحكم لأداة الدراسة

\begin{tabular}{|c|c|c|c|}
\hline $5-3.67$ & $3.66-2.34$ & 2.33 & الفئة \\
\hline الفئة الثالثة (مو افقة) & الفئة الثانية (محايدة) & الفئة الأولى (عدم المو افقة) & معيار الحكم \\
\hline
\end{tabular}

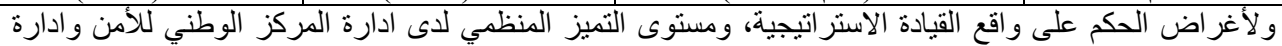

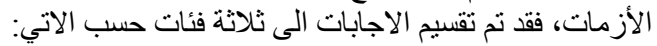

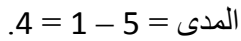

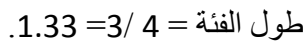

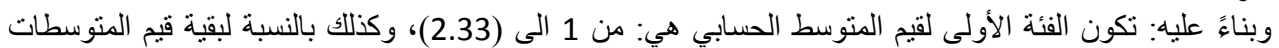
الحسابية. الجدول (3) يوضح معيار الحكم على مستوى القيادة الاستراتيجية، و مستوى التئية التميز المنظمي في المركز

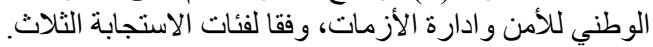

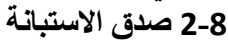

ويقصد به إلى أي مدى الاستبانة صالحة لقياس ما وضعت لقياسه. ولقياس صدق وثبات الاستبانة نم استخدام الاختبار

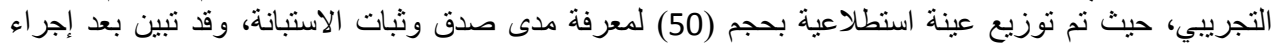

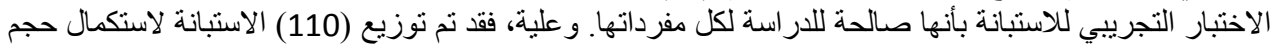

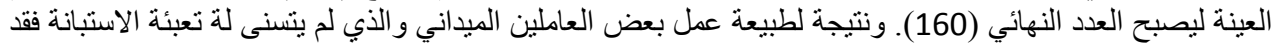

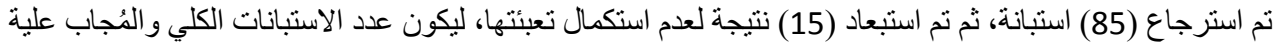

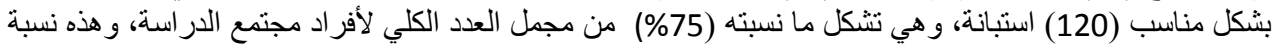

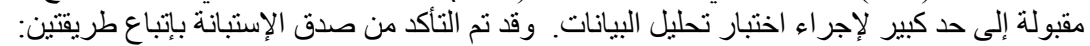

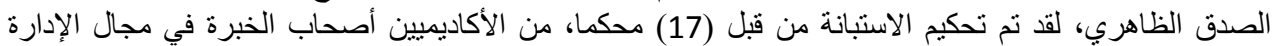

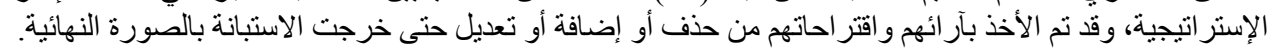




\section{Strategic Leadership Competencies and its Impact ....}

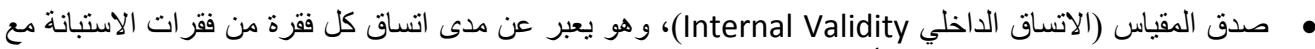

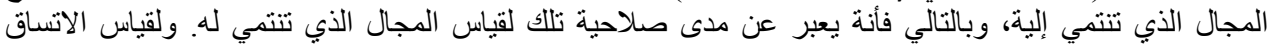
الداخلي لكل فقرة مع المجال الذي تنتمي إلية تم قياس معامل الارتباط بين كل فقرة و الدرجة الكلية للمجال نفسه.

جدول رقم (4). معاملات الارتباط بين كل فقرة من فقرات "جدار ات التفكير الاستر اتيجي" و الدرجة للكلية للمجال

\begin{tabular}{|c|c|c|}
\hline 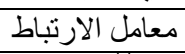 & 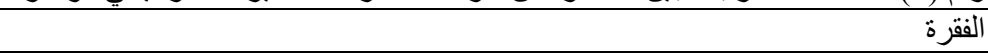 & 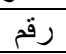 \\
\hline $0.364^{* *}$ & يتوفر لدى إدارة المركز تصور و اضح للفرص و التهديدات المحتملة & .1 \\
\hline $0.605^{*}$ & تتنبى إدارة المركز توجه استر اتيجي للتطوير & 2 \\
\hline $0.648^{* *}$ & تعمل إدارة المركز على تخصيص الموارد اللازمة لتحقيق الإستر اتيجية & .3 \\
\hline $0.715^{* *}$ & تشجع إدارة المركز على توليد أفكار جديدة & .4 \\
\hline $0.753^{* *}$ & تتبنى إدارة المركز الأفكار الجديدة للحصول على مزيد من العائدات (مادية أو غير مادية) & .5 \\
\hline $0.722^{*}$ & تعمل إدارة المركز على تحليل أسباب التغير ات الحاصلة في البيئة الدحبطة & .6 \\
\hline $0.554^{* *}$ & تسعى إدارة المركز إلى توفير المعلومات اللازمة لتحليل المخاطر الحالية والمستقبلية & .7 \\
\hline $0.599^{* *}$ & تقوم إدارة المركز بالاستفادة من نتائج الدراسات الميدانية لتحليل احتياجات المؤسسات ذات & .8 \\
\hline $0.638^{* *}$ & تقوم إدارة المركز بدر اسة تغير ات اتجاهات المؤسسات المعنية & .9 \\
\hline $0.660^{* *}$ & لادى إدارة المركز ثقافة التعلم من الخبرات السابقة ومن أخطاء الآخرين & .10 \\
\hline $0.650^{* *}$ & يتم الاعتماد على المعلومات من مصادر مختلفة لتحسين الوضع التنافسي للمركز & .11 \\
\hline $0.684^{* *}$ & يتم تحديد الفرص التي تم اكتثافها اعتمادا على مختلف المعلومات & .12 \\
\hline $0.704^{* *}$ & يتم دمج الأفكار مع بعضها لبعض وصو لا إلى أفكار جديدة & .13 \\
\hline $0.567^{* *}$ & طرح عدد من الحلول البديلة للمشكلة ومحاولة خلق تكامل بين تلك الحلول & .14 \\
\hline $0.577^{* *}$ & نأخذ بعين الاعتبار في عملية اتخاذ القرار جميع أبعاد الشكلة & .15 \\
\hline
\end{tabular}

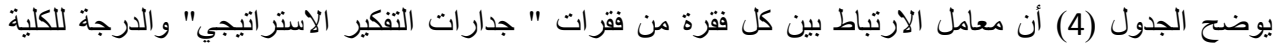

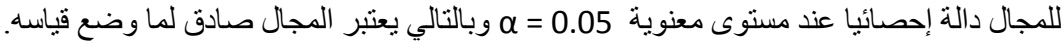

جدول رقم (5). معاملات الارتباط بين كل فقرة من فقرات "جدارات القيادة" و الدرجة للكلية للمجال

\begin{tabular}{|c|c|c|}
\hline معامل الارتباط (بيرسون) & 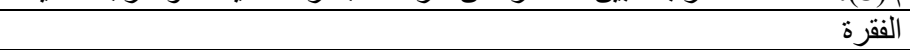 & رقم \\
\hline $0.626^{*}$ & تحرص الإدارة على التنبؤ بالتغير ات الحاصلة في البيئة الخارجية & .1 \\
\hline $0.658^{*}$ & توفر إدارة المركز المعرفة اللازمة للعاملين & .2 \\
\hline $0.729^{* *}$ & تحرص إدارة المركز على تحقيق أهدافها & .3 \\
\hline $0.745^{* *}$ & تشجع إدارة المركز العاملين على القيام بمهام العمل و الأدوار و المسؤوليات & .4 \\
\hline $0.578^{* *}$ & تقو قدر إدات المركز بتحويل الأهداف طويلة الددى إلى خطط إجر ائية واضحة تتسجم & .5 \\
\hline $0.632^{*}$ & تاتعل إدارة المركز على مشتاركة الآخرين و اكتساب دعمهم من خلال عملية & .6 \\
\hline $0.589^{* *}$ & تعمل إدارة المركز على إثر الك جميع العاملين بتقييم خطوات العمل & .7 \\
\hline $0.486^{*}$ & توفر الإدارة نظام اتصالات فعال داخل المركز & .8 \\
\hline $0.532^{*}$ & و التميز إدارة المركز بيناء علاقات متميزة مع الآخرين في المركز وخارج المركز & .9 \\
\hline $0.530^{* *}$ & تحرص إدارة المركز على تقديم قيم عالية لزبائنها & .10 \\
\hline
\end{tabular}

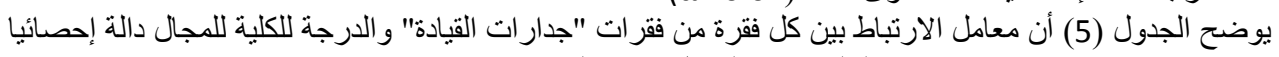

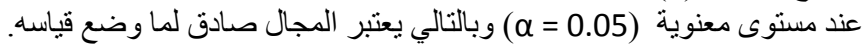


Journal of Social Sciences (COES\&RJ-JSS), 8(1), pp.106-138

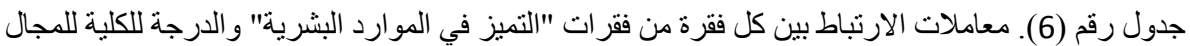

\begin{tabular}{|c|c|c|}
\hline معامل الارتباط (بيرسون) & 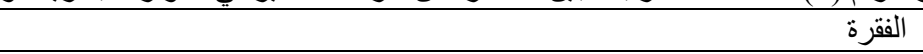 & 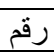 \\
\hline $.629^{* *}$ & تعمل إدارة المركز على إيجاد قو اعد بيانات متاحة لجميع المتعاملين معها & .1 \\
\hline $.602^{* *}$ & تحرص إدارة المركز على توثيق أعمالهاو الرجوع إليها عند الحاجة & .2 \\
\hline $.548^{* *}$ & أو مشكلة دعينة تو اجه اليل معز ملومات امن وذللك لسهولة الرجوع إلية عند حدوث قضية & .3 \\
\hline $.743^{* *}$ & تدرس إدارة المركز احتباجاتنا التدرييية باستمرار & .4 \\
\hline $.733^{* *}$ & يتمتحليلودراسةخبرات ومهار ات الشخص المرشح للتعيينو اختبارتلالك المهار ات & .5 \\
\hline $.690^{* *}$ & تعمل إدارة المركز على تطوير مهارات العاملين لديها & .6 \\
\hline $.759^{* *}$ & تدعم إدارة المركز حرية الأفر اد في تقديم أفكار هم ومبادر اتهم & .7 \\
\hline $.769^{* *}$ & مكافأة مقدمي الاقتر احات الجيدة و الَّفيدة & .8 \\
\hline $.770^{* *}$ & تحرص إدارة المركز على مناقشة الأفكار و الاقتر احات مع العاملين & .9 \\
\hline $.809^{* *}$ & يتعلم المركز من تجارب وقصص النجاح للأفر اد و المؤسسات الأخرى & .10 \\
\hline $.743^{* *}$ & تعمل إدارة المركز على تقييم بر امج التعلم للعاملين & .11 \\
\hline $.527^{* *}$ & تحرص إدارة المركز على إدخال كل ما هو جديد في عملياتها التكنولوجية & .12 \\
\hline
\end{tabular}

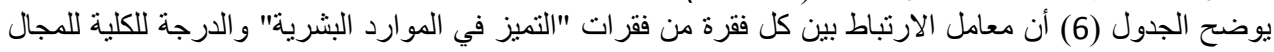

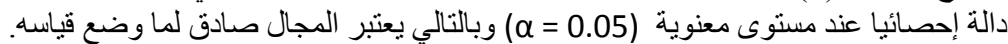

جدول رقم (7). معاملات الارتباط بين كل فقرة من فقرات " التميز في الهيكل التنظيمي " و الدرجة للكلية للمجال

\begin{tabular}{|c|c|c|}
\hline معامل الارتباط & 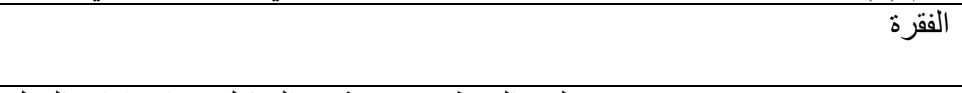 & رقم \\
\hline $0.739^{* *}$ & لدى الموظفين مرونة في التعامل مع إجر اءات العمل & .1 \\
\hline $0.606^{* *}$ & تحرص إدارة المركز على الاستفادة من التنظيم الغير رسمي باستمر ار & .2 \\
\hline $0.689^{* *}$ & تحرص الإدارة على تبليغ العاملين بإبداعاتها باستمر ار & .3 \\
\hline $0.714^{* *}$ & تحرص الإدارة على مر اجعة هيكلها التنظيمي باستمر ار & .4 \\
\hline
\end{tabular}

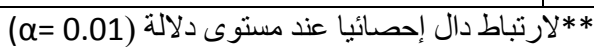

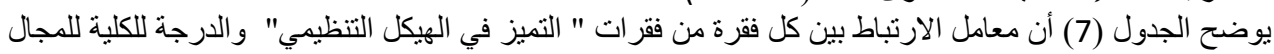

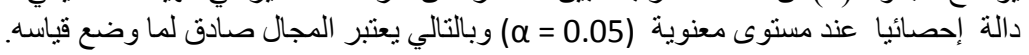

جدول رقم (8). معاملات الارتباط بين كل فقرة من فقر ات بلت "التميز في الثقافة التنظيمية" و الدرجة للكلية للمجال

\begin{tabular}{|c|c|c|}
\hline $\begin{array}{r}\text { (بيرسون الارنباط) } \\
\text { معامل }\end{array}$ & الفقرة & رقم \\
\hline $.645^{* *}$ & تحقدصة إدارة المركز على الاستجابة لاحتياجات المؤسسات المعنية في الخدمات & .1 \\
\hline $.531^{*}$ & إليها المرز قادر على تحليل بيئته واتخاذ قرارات التعامل مع النتائج التي ثم التوصل & .2 \\
\hline $.621^{*}$ & تضع إدارة المركز تصور ات وسيناريو هات للمستقبل & .3 \\
\hline $.649^{* *}$ & يوجد تو افق بالطريقة التي نعمل بها الأشياء في المركز & .4 \\
\hline $.692^{*}$ & يتشارك العاملون في المركز بوجهات نظر مشتركة لطرق العمل & .5 \\
\hline $.647^{*}$ & تتسم طريقة العمل بالمركز بالتكامل بين مختلف الوحدات العامله فيه & .6 \\
\hline .557 & تتسم رسالة المركز بالوضوح لجميع العاملين & .7 \\
\hline $.712^{*}$ & هناك إجماع من إدارة المركز وموظفيه على نظرتهم للمستقبل & .8 \\
\hline $.741^{*}$ & يتم مشاركة الموظفين بالمعلومات كي تكون متاحة للجميع بسهولة & .9 \\
\hline .777 & يشترك جميع العاملين في عملية التخطيط لأهداف المركز & .10 \\
\hline $.773^{* *}$ & يتسم عمل المركز بالروح المعنوية العالية لدى جميع العاملين & .11 \\
\hline
\end{tabular}

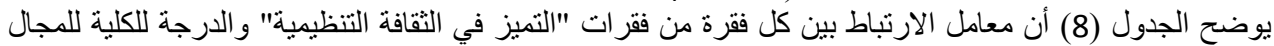

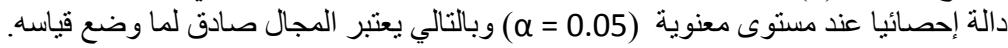


Strategic Leadership Competencies and its Impact ....

جدول رقم (9). معاملات الارتباط بين كل فقرة من فقرات "الالتز ام المنظمي" والدرجة للكلية للمجال

\begin{tabular}{|c|c|c|}
\hline $\begin{array}{rr}\text { معامل } \\
\end{array}$ & 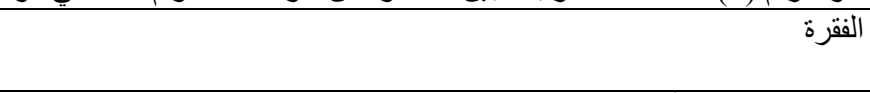 & رقم \\
\hline $.403^{* *}$ & ستكون سعيدا إذا أمضيت بقية حياتك المهنية في المركز & .1 \\
\hline $.614^{* *}$ & تشعر وكأنك جزء من عائلة هذه المركز & .2 \\
\hline $.509^{* *}$ & تشعر بإحساس قوي بالانتماء لهذه المركز & 3 \\
\hline $.443^{* *}$ & تعتقد أنه من الصعب عليك ترك هذه المركز للعمل في مكان أخر & .4 \\
\hline $.563^{* *}$ & أعلى تستر بالعمل في هذه المركزولو عرض عليك العمل في مؤسسة أخرى وبامتياز & .5 \\
\hline $.729^{* *}$ & تفكر كثير ا عند اتخاذك قرار بتغيير مكان العمل في هذه المركز & .6 \\
\hline $.676^{*}$ & تعتقد أن العاملين في المركز يؤمنون بأهدافه & .7 \\
\hline $.630^{* *}$ & تعتقد بأن الانتقال من المركز لا يجول في خاطرك & .8 \\
\hline $.459^{* *}$ & تؤمن بأن الو لاء المستمر للمركز الذي تعمل فيه يعتبر قيمة أخلاقية & .9 \\
\hline
\end{tabular}

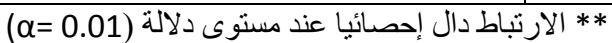

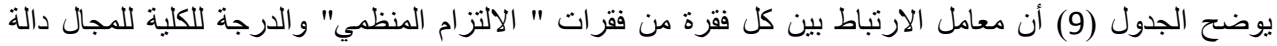

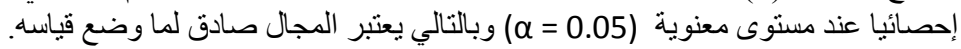

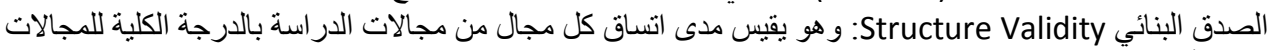
جميعا أو جميع فقر ات الاستبانة.

جدول رقم (10). معامل الارتباط بين درجة كل مجال من مجالات الاستبانة و الدرجة الكلية للاستبانة

\begin{tabular}{|c|c|c|}
\hline معامل الارتباط (بيرسون) & المجال & رقم \\
\hline $.739^{* *}$ & جدار ات التفكير الاستر اتيجي & .1 \\
\hline $.732^{* *}$ & جدار ات القيادة & .2 \\
\hline $.790^{* *}$ & التميز في الموارد البشرية & .3 \\
\hline $.699^{* *}$ & التميز في الهيكل المنظمي & .4 \\
\hline $.732^{* *}$ & التميز في الثقافة المنظمية & .5 \\
\hline $.741^{* *}$ & الالتز ام المنظمي & .6 \\
\hline
\end{tabular}

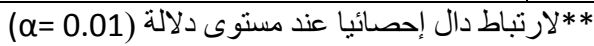

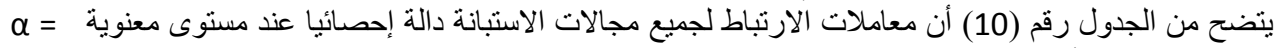

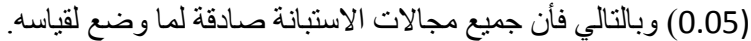

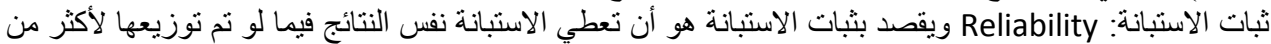

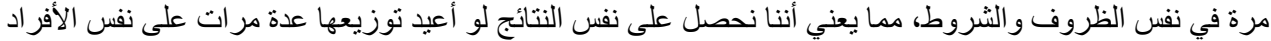

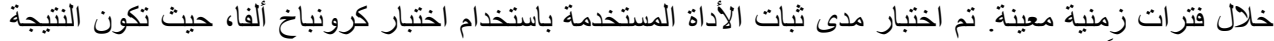

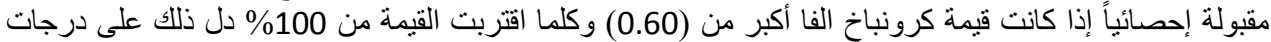

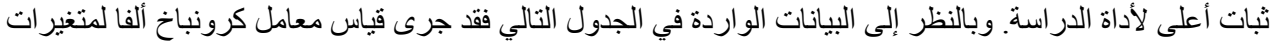

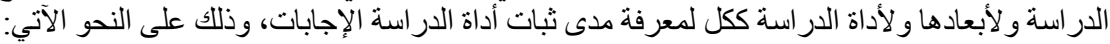
الجدول (11). معامل كرونباخ لأبعاد أداة الدراسة الأنة

\begin{tabular}{|c|c|c|}
\hline قيمة ألفا & 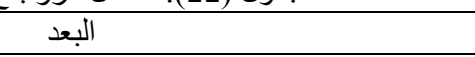 & 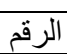 \\
\hline 0.889 & جدارات التفكير الإستر اتيجي & 1 \\
\hline 0.812 & الجدار ات القيادية & 2 \\
\hline 0.913 & \multicolumn{2}{|l|}{ جدارات القيادة الإستر اتيجية } \\
\hline 0.900 & التميز في الموارد البشرية & 3 \\
\hline 0.627 & التميز في الهيكل التنظيمي & 4 \\
\hline 0.870 & التميز في الثقافة المنظمية & 5 \\
\hline 0.940 & \multicolumn{2}{|l|}{ التمبز المنظمي } \\
\hline 0.898 & الإلتز ام المنظمي & 6 \\
\hline 0.955 & \multicolumn{2}{|l|}{ جميع الفقرات } \\
\hline
\end{tabular}




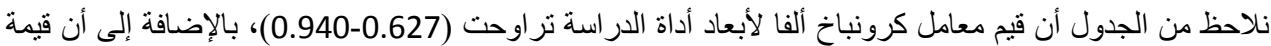

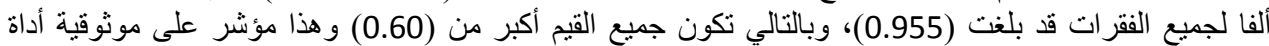

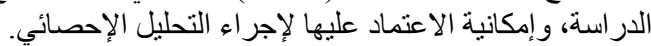

\begin{tabular}{|c|c|c|}
\hline $\begin{array}{c}\text { الاحتمالية } \\
\text { (Sig.) } \\
\text { (Sigمة }\end{array}$ & المجال & 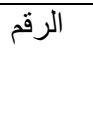 \\
\hline .077 & جدار ات التفكير الاستر اتيجي & .1 \\
\hline 840. & جدارات القيادة & .2 \\
\hline .122 & التميز في الموارد البشرية & .3 \\
\hline .094 & التميز في الهيكل التنظيمي & .4 \\
\hline .087 & التميز في الثقافة التنظيمية & .4 \\
\hline 533. & الالتزام المنظمي & .5 \\
\hline .0875 & \multicolumn{2}{|c|}{ جيع مجالات الاستبانة } \\
\hline
\end{tabular}

تم استخدام مقياس Kolomogrov- Smirnov (12) لقياس فيما إذا كان توزيع البيانات طبيعي أم غير طبيعي. حيث

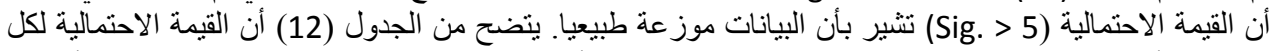
المجالات أكبر من مسنوى الدلالة (

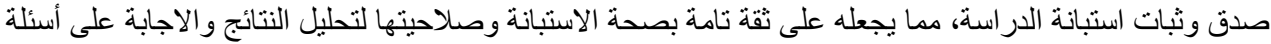

2-10 الأساليب الاحصائية المستخدمة

النسب المئوية و التكرار ات والاتئ المتوسط الحسابي؛ يستخدم هذا الأمر بشكل أساسي لأغر اض معرفة تكرار فئات متغير ما ويتم الاستفادة منها في وصف ولتف مجتمع الدر استة. اختبار مقياس التوزيع الطبيعي (Kolomogrov- Smirnov) ؛لاختبار توزيعة الإنية البيانات. اختبار (Cronbach's Alpha)؛ لقياس ثبات فقران النقات الاستبانة.

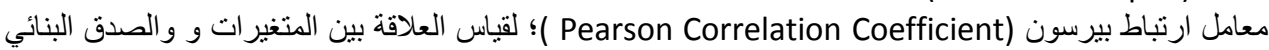
للاستبانة وكذلك الاتساق الداخلي لفقرات الاستبانة.

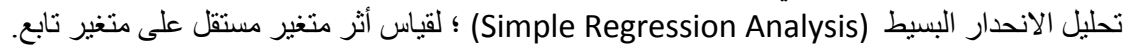
تحليل الانحدار المتعدد (Multiple Rgression Analysis)؛ لقياس أثر عدد من المتغيرات المستقلة على متغير تابت تحليل ومناقشة النتائج تناول هذا الفصل تحليل نتائج الدراسة ومناقتشتها بعد تطبيق أداة الدراسة، حيثُ نم استخدام المنظومةالإحصائية

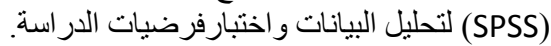
3-1 وصف المتغيرات الايموغرافية التئية

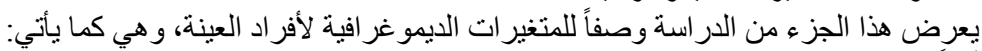
الجدول (13). وصف أفر اد العينة حسب متغير الجنس

\begin{tabular}{|c|c|c|c|}
\hline النسبة المئوية & التكر ار & الفئة & المتغير \\
\hline $83.3 \%$ & 120 & ذكر & \multirow[t]{2}{*}{ الجنس } \\
\hline $16.7 \%$ & 40 & أنثى & \\
\hline $100 \%$ & 160 & & \\
\hline
\end{tabular}

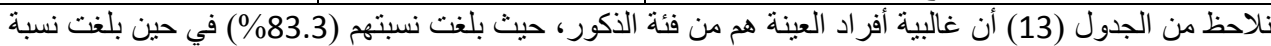

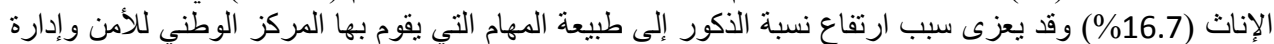

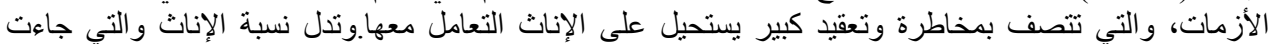

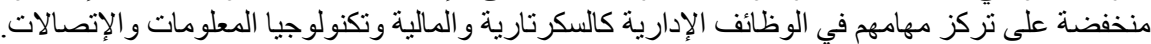


Strategic Leadership Competencies and its Impact ....

الجدول (14). وصف أفر اد العينة حسب متغير الفئة العمرية

ثانياً: الفئة العمرية

\begin{tabular}{|c|c|c|c|}
\hline النسبة المئوية & التكر ار & الفئة & المتغير \\
\hline $25.0 \%$ & 40 & أقل من 30 & \multirow[t]{4}{*}{ لفئة العمرية } \\
\hline $44.2 \%$ & 68 & 30- أقل من 40 & \\
\hline $25.8 \%$ & 41 & 40-أقل من 50 & \\
\hline $5.0 \%$ & 11 & 50 فأكثر & \\
\hline $100 \%$ & 160 & & \\
\hline
\end{tabular}

نلاحظ من الجدول أن غالبية أفر اد العينة هم من الفئة العمرية (30-أقل من 40) و هذا يدل على أن المهام المطلوبة في هذا المجال تحتاج إلى شباب.

\begin{tabular}{|c|c|c|c|}
\hline النسبة المئوية & التكر ار & الفئة & المتغير \\
\hline $13.3 \%$ & 21 & دبلوم & \multirow[t]{4}{*}{ لمؤهل العلمي } \\
\hline $65.8 \%$ & 99 & بكالوريوس & \\
\hline $19.2 \%$ & 33 & ماجستير & \\
\hline $1.7 \%$ & 7 & دكتور اه & \\
\hline $100 \%$ & 160 & \multicolumn{2}{|c|}{ المجموع } \\
\hline
\end{tabular}

نلاحظ من الجدول أن حملة شهاده البكالوريوس قد شكلت غالبية أفر اد العبنة حيث بلغت نسبتهم (65.8\%) و هذا

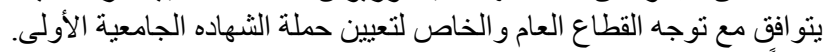
رابعاً: المستوى الوظيفي

\begin{tabular}{|c|c|c|c|}
\hline النسبة المئوية & التكر ار & الفئة & المتغير \\
\hline $2.5 \%$ & 8 & مدير عام & \multirow[t]{4}{*}{ المستوى الوظيفي } \\
\hline $4.2 \%$ & 10 & مدير وحدة & \\
\hline $12.5 \%$ & 20 & رئيس قسم & \\
\hline $80.8 \%$ & 122 & موظف دون مسؤولية & \\
\hline $100 \%$ & 160 & & \\
\hline
\end{tabular}

نلاحظ من الجدول أن الموظف دون مسؤولية إدارية قد شكلوا الغالبية العظمى من أفراد العينة حيث بلغت نوان نسبتهم

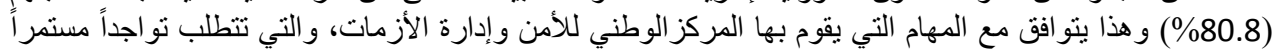
من الكو ادر البشرية العاملة في المركز في الميدان.

\begin{tabular}{|c|c|c|c|}
\hline \multicolumn{4}{|c|}{ الجدول (17). وصف أفر اد العينة حسب متغير سنوات الخبرة } \\
\hline النسبة المئوية & 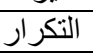 & الفئة & 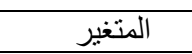 \\
\hline $24.2 \%$ & 39 & أقل من 5 & 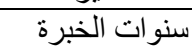 \\
\hline $41.7 \%$ & 69 & من 5-أقل من10 & \\
\hline $15.0 \%$ & 23 & من 10_أقل من 15 & \\
\hline $19.2 \%$ & 29 & 15 فأكثر & \\
\hline $100 \%$ & 160 & & \\
\hline
\end{tabular}

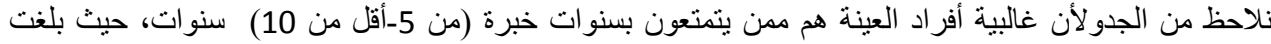
نسبتهم (41.7\%) و هذا يدل على إمتلاك أفراد العينة خبرة عالية في إداد إدارة الأزمات، الأمر الذي من شإنه أن ينعكس على قدرتهم في أداء المهام الموكلة إليهم.

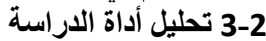

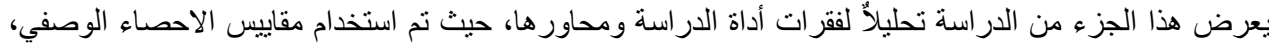
كالمتوسطات الحسابية والانحر افات المعيارية والأهمية النسبية، وكانت النتائج على النحو التالي: 
3-3 وصف متغير الدراسة المستقل

وقد تمثل المتغير المستقل بجدار ات القياد القيادة الاستر اتيجية، و الذي تضمن:

أولاً: جدارات التفكير الاستراتيجي التئي

الجدول (18). المتوسطات الحسابية والانحر افات المعيارية و الأهمية النسبية لاجابات افر اد العينه لفقرات جدارات

\begin{tabular}{|c|c|c|c|c|c|}
\hline المستوى & 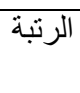 & 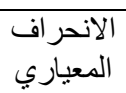 & ال الحسابي & 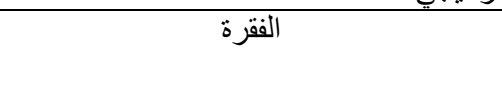 & 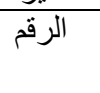 \\
\hline مرتفع & 4 & 0.709 & 4.208 & لتفوصر والثى إدارة المركز تصور و واضح & .1 \\
\hline مرتفع & 2 & 0.641 & 4.225 & للتبنى إدارة المركز توجه استراتيجي & .2 \\
\hline مرتفع & 6 & 0.763 & 4.175 & تعلازمة إدارة المركز الإسنر على تخية تصيص الموارد & .3 \\
\hline 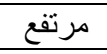 & 13 & 0.927 & 3.925 & تشجع إدارة المركز على توليد أفكار جديدة & .4 \\
\hline 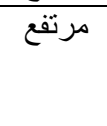 & 11 & 0.883 & 4.042 & 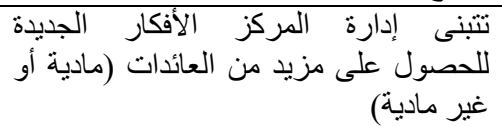 & .5 \\
\hline 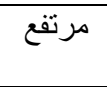 & 8 & 0.857 & 4.150 & تععل إدارة المركز في على البيئة المحيطيل أسباب & .6 \\
\hline مرتفع & 1 & 0.656 & 4.300 & 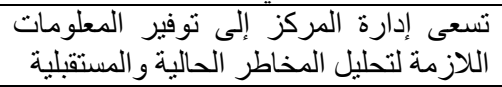 & .7 \\
\hline 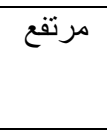 & 9 & 0.810 & 4.092 & 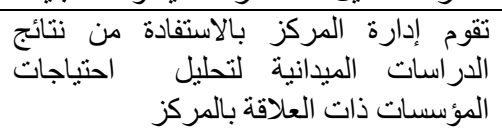 & .8 \\
\hline مرتفع & 15 & 0.813 & 3.833 & تقؤم إدارة المركز بدراسة تغيرات اتجاهات & .9 \\
\hline 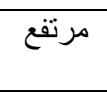 & 7 & 0.733 & 4.158 & السابقة ومن أخطاء الآخرين التعلم من الخبرات & .10 \\
\hline مرتفع & 3 & 0.712 & 4.217 & يتم الاعتماد على التى المعلومات من مصنادين للمركز & .11 \\
\hline 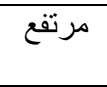 & 14 & 0.922 & 3.875 & علتى تحديد الفرصل التي تم اكتثافها اعتمادا & .12 \\
\hline مرتفع & 12 & 0.756 & 3.983 & يتث أفكار جديدة الأفكار مع بعضها لبعض وصولا & .13 \\
\hline مرتفع & 10 & 0.683 & 4.067 & ومحاولة غلقد تكامل بين تللك الحلول الحلّل للمشكلة & .14 \\
\hline مرتفع & 5 & 0.639 & 4.192 & نميع أبعاد المشكلة الأبار في عملية اتخاذ القرار & .15 \\
\hline مرتفع & & 0.483 & 4.096 & المقياس العام & \\
\hline
\end{tabular}

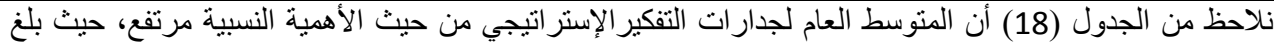

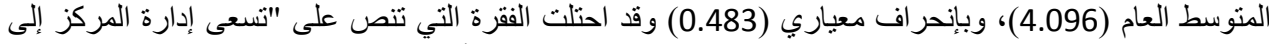

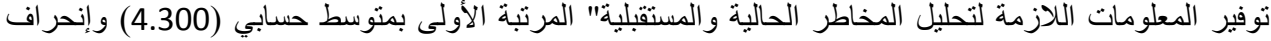

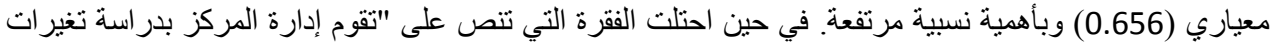

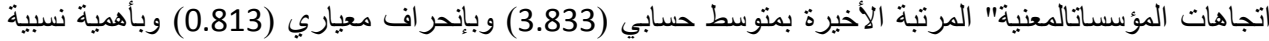

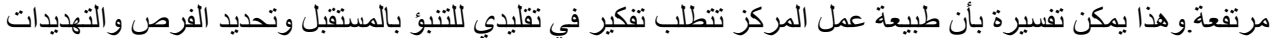


Strategic Leadership Competencies and its Impact ....

ثانيا: الجدارات القيادية

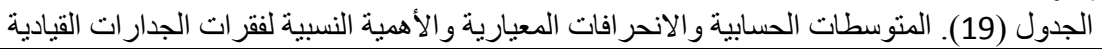

\begin{tabular}{|c|c|c|c|c|c|}
\hline 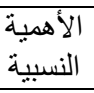 & الرتبة & 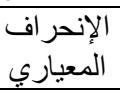 & الحسابي & الفقرة & 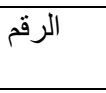 \\
\hline مرتفع & 5 & 0.612 & 4.142 & تحرصلة في الإدارة البيئة على التنبؤ بالتغيرات & .16 \\
\hline مرتفع & 7 & 0.789 & 4.092 & تلعاملين إدارة المركز المعرفة اللازمة & .17 \\
\hline مرتفع & 3 & 0.729 & 4.175 & تحرص إدارة المركز على تحقيق أهدافها & .18 \\
\hline مرتفع & 6 & 0.862 & 4.117 & تشتجع إدارة المركز العمل و الأدوار و والمسؤولين القيات & .19 \\
\hline مرتفع & 9 & 0.654 & 4.025 & 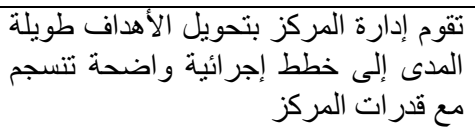 & .20 \\
\hline مرتفع & 4 & 0.706 & 4.150 & 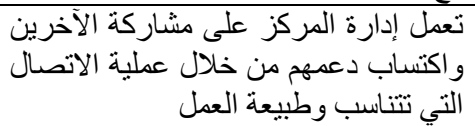 & .21 \\
\hline مرتفع & 10 & 0.941 & 3.650 & 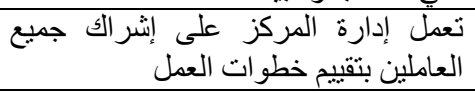 & .22 \\
\hline مرتفع & 2 & 0.695 & 4.267 & توفر الإدارة نظام اتصالات فعال داخل & .23 \\
\hline مرتفع & 1 & 0.693 & 4.300 & 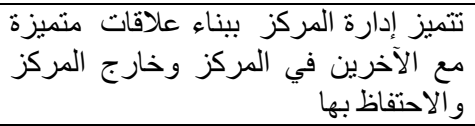 & .24 \\
\hline مرتفع & 8 & 0.652 & 4.058 & تلحرصنئ إدارة المركز على تقديم قيم عالية & .25 \\
\hline مرتفع & & 0.450 & 4.098 & المقياس العام & \\
\hline
\end{tabular}

نلاحظ من الجدول (19) أن المتوسط العام لجدارات القيادية من حيث الأهمية النسبية مرتفع، حيث بلغ المتوسط العام

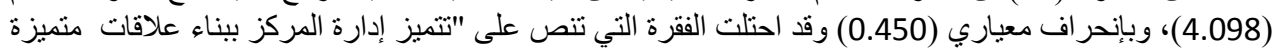

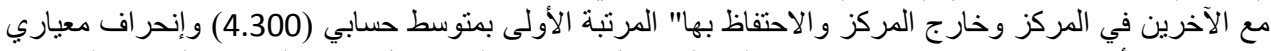

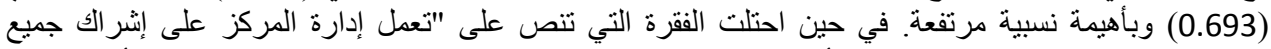

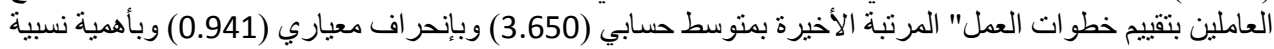

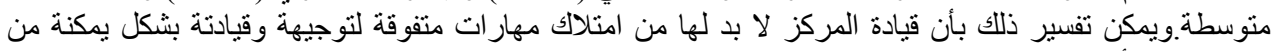

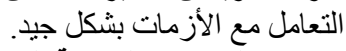

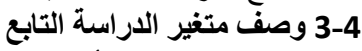

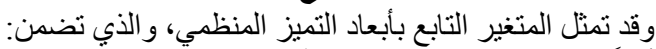

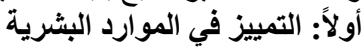

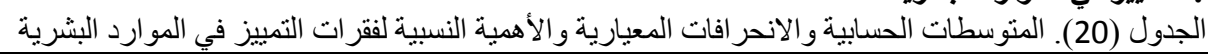

\begin{tabular}{|c|c|c|c|c|c|}
\hline المستوى & الزتبة & المعياري & الحسابي & الفقزة & 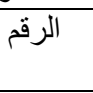 \\
\hline مرتفع & 7 & 0.862 & 3.883 & 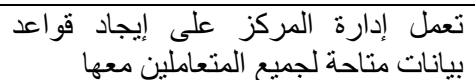 & .26 \\
\hline 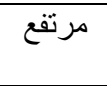 & 2 & 0.724 & 4.117 & تو الرجوص إدارة المركز على الحاجة توثيق أعمالها & .27 \\
\hline مرتفع & 3 & 0.690 & 4.058 & 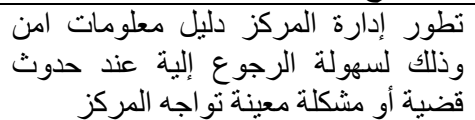 & .28 \\
\hline 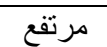 & 5 & 0.850 & 3.908 & تدرس إدارة المركز احتياجاتنا التدريبية & .29 \\
\hline
\end{tabular}


Journal of Social Sciences (COES\&RJ-JSS), 8(1), pp.106-138

\begin{tabular}{|c|c|c|c|c|c|}
\hline & & & & باستمر ار & \\
\hline 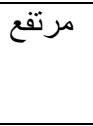 & 4 & 0.954 & 3.925 & 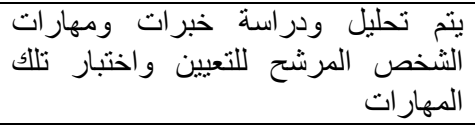 & .30 \\
\hline 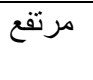 & 4 & 0.909 & 3.925 & تعمل إدارة المركز على تطوير مهارات & .31 \\
\hline 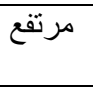 & 8 & 0.913 & 3.875 & أفكار هم وإدمبادر اتهركز حرية الأفر اد في تقديم & .32 \\
\hline 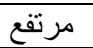 & 11 & 1.007 & 3.708 & مكافأة مقدمي الاقتر احات الجيدة و المفيدة & .33 \\
\hline مرتفع & 9 & 0.847 & 3.825 & تحرص الاقتر إدارة مع العركزلين على مناقشة الأفكار & .34 \\
\hline مرتفع & 6 & 0.818 & 3.892 & للافعر اد و المؤسسات الأخرى وقص تصص النجاح & .35 \\
\hline 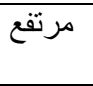 & 10 & 0.900 & 3.783 & تلعمل إدارة المركز على تقييم برامج التعلم & .36 \\
\hline 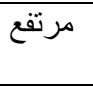 & 1 & 0.771 & 4.292 & تحرص جديد في عملياتها التكنولوجية إدخال كل ما & .37 \\
\hline 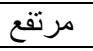 & & 0.593 & 3.933 & المقياس العام & \\
\hline
\end{tabular}

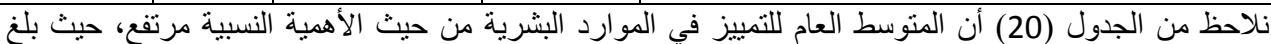

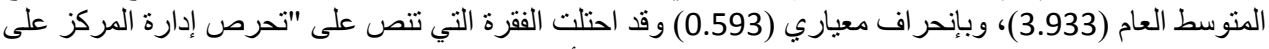

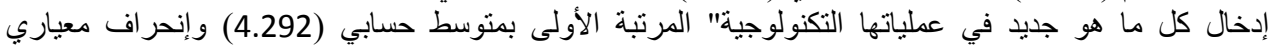

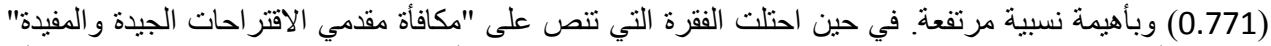

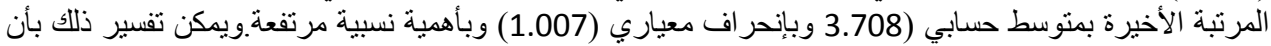

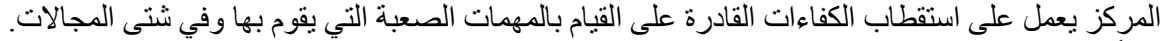
ثانياً: التمييز في الهيكل التنظيمي التئي الجذول (21). المنوسطات الحسابية و الانحر افات المعيارية والأهمية النسبية لفقر ات التمييز في الهيكل التنظيمي

\begin{tabular}{|c|c|c|c|c|c|}
\hline المسنوى & الرتبة & 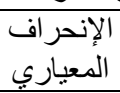 & الحستيط & الفقرة & الرقم \\
\hline مرتفع & 3 & 0.898 & 3.842 & إلجر اءات العملين مرونة في التعامل مع & .38 \\
\hline مرتفع & 2 & 0.731 & 3.892 & تلتنظص غير الدارة المركي باستمر على الاستفادة من & .39 \\
\hline مرتفع & 1 & 0.792 & 3.942 & تإبداعاتها باستمر الإدارة على تبليغ العاملين & .40 \\
\hline مرتفع & 4 & 0.837 & 3.767 & تحرص التنظيمي بإدارة على مراجعة هيكلها & .41 \\
\hline & & 0.561 & 3.860 & الَّقياس العام & \\
\hline
\end{tabular}

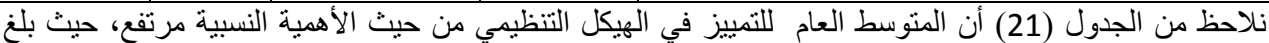

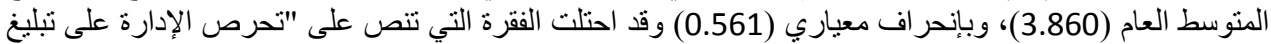

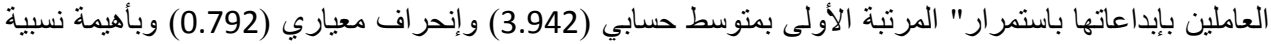

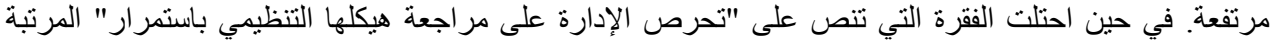

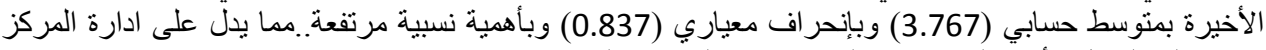

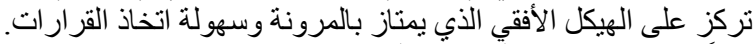

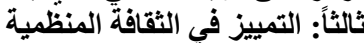

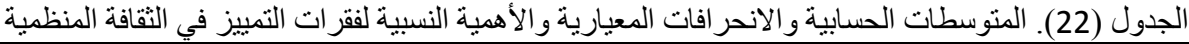

\begin{tabular}{|c|c|c|c|c|c|}
\hline 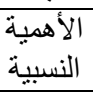 & الرتبة & ال الإنحرياف & 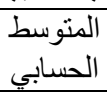 & الفقرة & الرقم \\
\hline مرتفع & 5 & 0.772 & 3.992 & تحؤسسات المعنية في الخدمات المقدمة المنة لاحتياجات & .42 \\
\hline
\end{tabular}


Strategic Leadership Competencies and its Impact ....

\begin{tabular}{|c|c|c|c|c|c|}
\hline 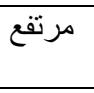 & 2 & 0.748 & 4.142 & التعامل مع النتائج التي تحمليل بيئته واتخاد التياذ قرارات & .43 \\
\hline 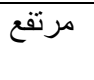 & 1 & 0.702 & 4.192 & للضمنقعل إدارة المركز تصورات وسيناريو هات & .44 \\
\hline 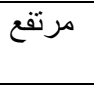 & 6 & 0.753 & 3.933 & يوجد توافق بالطريقة التي نعمل بها الأشياء في & .45 \\
\hline 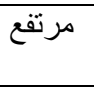 & 9 & 0.917 & 3.758 & يتشتركة لطرق العاملون في المركز بوجهات نظر & .46 \\
\hline مرتفع & 7 & 0.938 & 3.808 & الوحدات العاملة فيه بالمركز بالتكامل بين مختلف & .47 \\
\hline 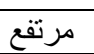 & 4 & 0.793 & 4.025 & تتسم رسالة المركز بالوضوح لجميع العاملين & .48 \\
\hline 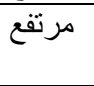 & 3 & 0.726 & 4.042 & نظرتهم إلمساعقبل من إدارة المركز وموظفيه على & .49 \\
\hline 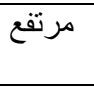 & 8 & 1.000 & 3.775 & للجميع بسهولة الموظفين بالمعلومات كي تكون متاحة & .50 \\
\hline 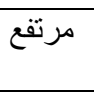 & 10 & 1.012 & 3.533 & المركز جميع العاملين في عملية التخطيط لأهداف & .51 \\
\hline 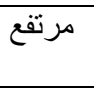 & 7 & 1.079 & 3.808 & جيميع العاملين المركز بالروح المعنوية العالية لدى & .52 \\
\hline مرتفع & & 0.572 & 3.910 & المقياس العام & \\
\hline
\end{tabular}

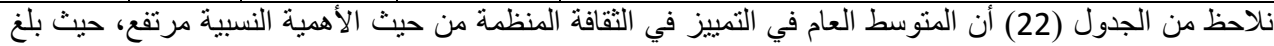

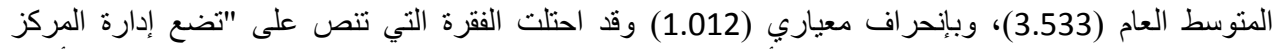

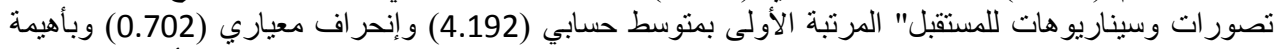

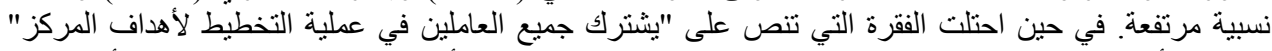

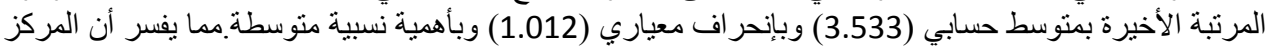

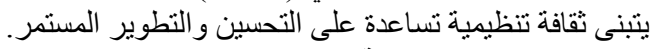

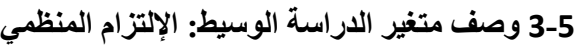

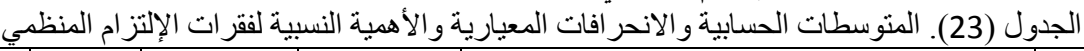

\begin{tabular}{|c|c|c|c|c|c|}
\hline الألهبية & 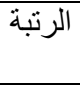 & المعياري الإن المر & المتوسط & 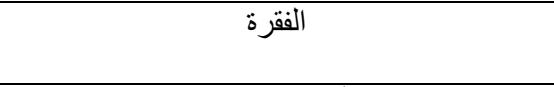 & 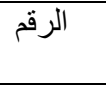 \\
\hline مرتفع & 3 & 0.863 & 4.058 & ستكون سعيدا إذا أمضيت بقية حياتك المهنية في & .53 \\
\hline مرتفع & 4 & 0.829 & 4.050 & تشعر وكأنك جز ء من عائلة هذه المركز & .54 \\
\hline مرتفع & 2 & 0.685 & 4.367 & تشعر بإحساس قوي بالانتماء لهذه المركز & .55 \\
\hline مرتفع & 5 & 0.957 & 3.992 & تلعملق في مكان اخن الصعب عليك ترك هذه المركز & .56 \\
\hline مرتفع & 7 & 1.118 & 3.900 & 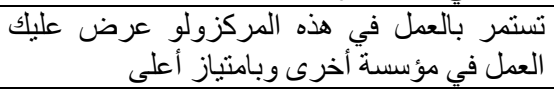 & .57 \\
\hline مرتفع & 6 & 0.930 & 3.992 & في هذه كثير ألمركز أتخاذك قرار بتغيير مكان العمل & .58 \\
\hline 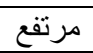 & 8 & 0.998 & 3.858 & تعتقفا أن العاملين في المركز يؤمنون بأهدافه & .59 \\
\hline 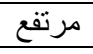 & 9 & 1.181 & 3.817 & تعتقد بأن الانتقال من المركز لا يجول في خاطرك & .60 \\
\hline مرتفع & 1 & 0.655 & 4.592 & تيعتبر قيمة أخلاقية ألاء المستمر للمركز الذي تعمل فيه & .61 \\
\hline 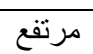 & & 0.689 & 4.069 & المقياس العام & \\
\hline
\end{tabular}

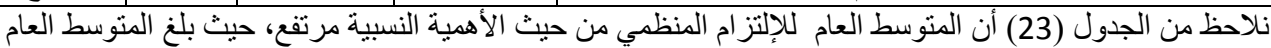

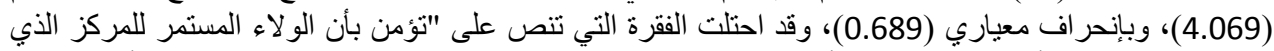
تعمل فيه يعتبر قيمة أخلاقية" المرتبة الأولى بمنوسط حسابي (4.952) و إنحر اف معياري (0.655) وبأهيمة نسبية 


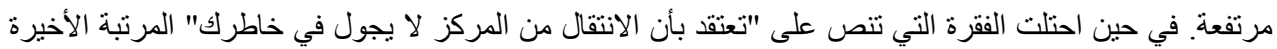

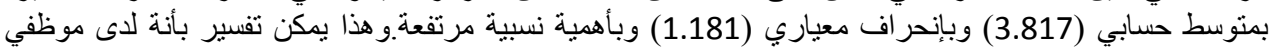
المركز الانتماء الثديد و الو لاء للمركز نتيجة توفير الكثير من المتطلبات والاحتياجات لهم، كما يدل على الوعي الجيد

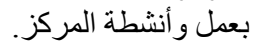

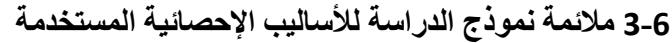

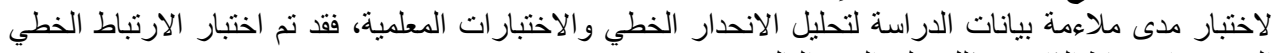

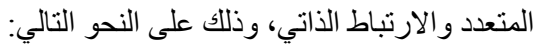

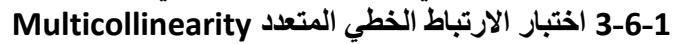

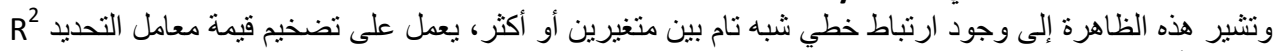

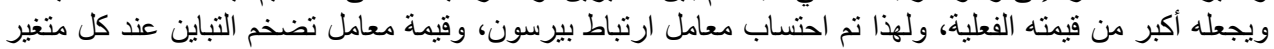

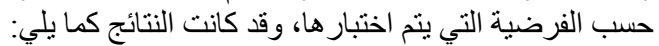
الجدول (24). مصفو فية الارتباط للمتغير ات المير المستقلة

\begin{tabular}{|c|c|c|}
\hline 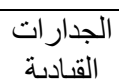 & جدارات التفكير الاستراتيجي & المتغير \\
\hline & 1.000 & جدار ات التفكير الاستر اتيجي \\
\hline 1.000 & $0.719 * *$ & الجدارات القيادية \\
\hline
\end{tabular}

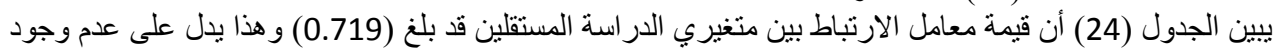

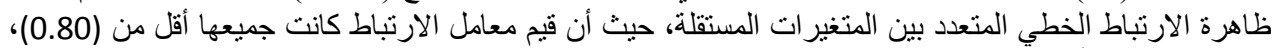

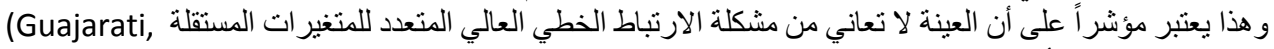

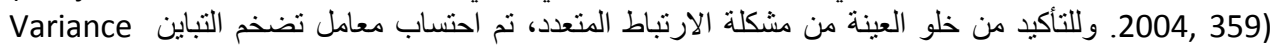
Inflation Factor (VIF)

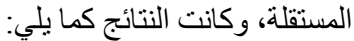
الجدول (25). نتائج اختبار الارتباط المتعدد بين المتغير ات المستقلة

\begin{tabular}{|c|c|c|}
\hline Tolerance & معامل تضخم التباين VIF & 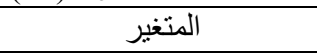 \\
\hline 0.483 & 2.068 & جدارات التفكير الاستر اتيجي \\
\hline 0.483 & 2.068 & الجدار ات القيادية \\
\hline
\end{tabular}

يبين الجدول (25) أن قيم معامل تضخم التباين كانت جميعها أكبر من العدد 1 و أقل من العدد 10، كما كانت قيمة العبة محصورة بين 0.1 و و1 مما يؤكد عدم وجود مشكلة الارتباط الخطي المتعدد بين جميع متغيرات الدر اسة المستقلة.

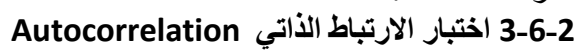

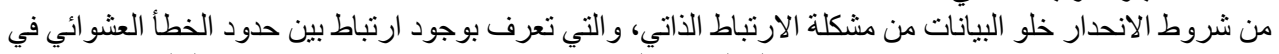

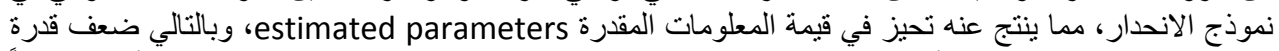

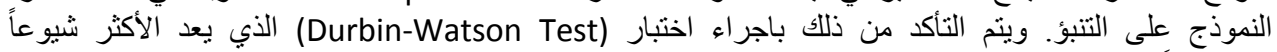

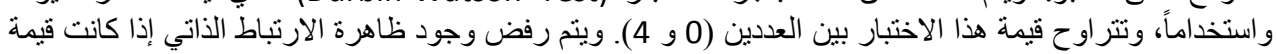
كساوي العدد 2، أو يقترب مناه. والجدول التالي يبين نتائج اختبار (D-W)

جدول رقم (26). اختبار مشكلة الارنباط الذاتي

\begin{tabular}{|c|c|c|}
\hline النتيجة & قيمة D-W المحسوبة & الفرضية \\
\hline لايوجد ارتباط ذاتي & 1.901 & H01-1 \\
\hline لايوجد ارتباط ذاتي & 1.862 & H01-2 \\
\hline لايوجد ارتباط ذاتي & 1.888 & $\mathrm{H} 01$ \\
\hline لايوجد ارتباط ذاتي & 1.905 & $\mathrm{H} 02-1$ \\
\hline لايوجد ارتباط ذاتي & 1.922 & $\mathrm{H} 02-2$ \\
\hline لايوجد ارتباط ذاتي & 1.979 & $\mathrm{HO2}$ \\
\hline لايوجد ارتباط ذاتي & 1.798 & $\mathrm{HO3}$ \\
\hline
\end{tabular}

نلاحظ ان قيم D-W للمتغير ات في الفرضيات المذكورة جميعها تقترب من العدد 2، مما يشير لخاطي لألو البيانات من مشكلة

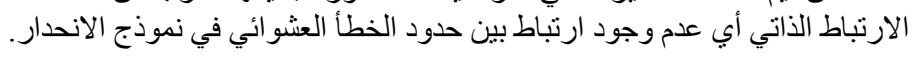




\section{Strategic Leadership Competencies and its Impact ....}

3-6-3 3 اختبار فرضيات الاراسة

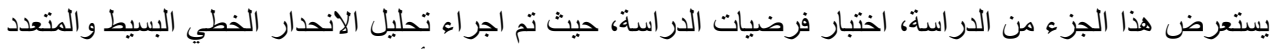
لاختبار الفرضيات الأولى والثانية والثالثة، كما تم اختبار (Simple and MultipleLinear Regression)

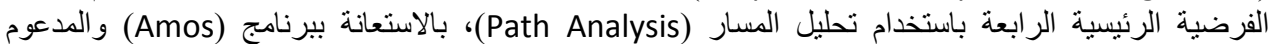

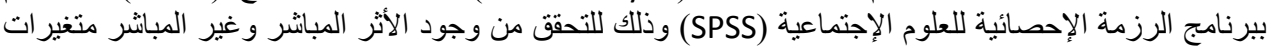

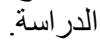
اختبار الفرضية الرئيسية الاولى دالى

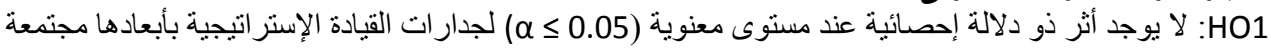

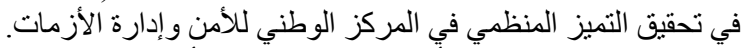

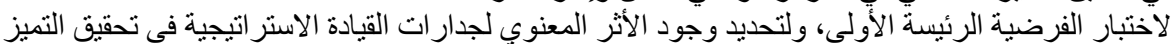

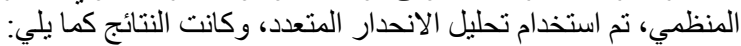

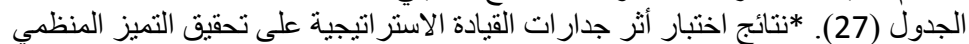

\begin{tabular}{|c|c|c|c|c|c|c|c|c|c|c|}
\hline \multicolumn{5}{|c|}{ جدول المعاملات } & \multicolumn{3}{|c|}{$\begin{array}{c}\text { تحليل التباين } \\
\text { ANOVA }\end{array}$} & \multicolumn{2}{|c|}{$\begin{array}{c}\text { ملخص النموذنج } \\
\text { Model Summery }\end{array}$} & \multirow{2}{*}{ التنغير } \\
\hline Sig $\mathrm{t}$ & $T$ & الخعياري & $B$ & البيان - البيان & Sig F & الحرجة & المحسوبة & التحديد & الارتباطل Re & \\
\hline 0.005 & 2.844 & 0.055 & 0.156 & جدار ات التفكير الاستر اتيجي & $\begin{array}{c}0.00 \\
0\end{array}$ & 117 & 339.693 & 0.853 & 0.924 & التمقيق \\
\hline 0.000 & 15.971 & 0.045 & 0.717 & الجدار ات القيادية & & 119 & & & & \\
\hline
\end{tabular}

* يكون التأثير ذا دلالة إحصائية عند مستوى (a 0.05 (

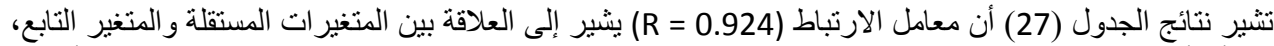

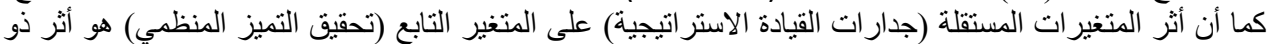

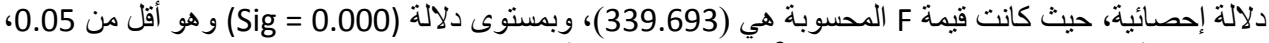

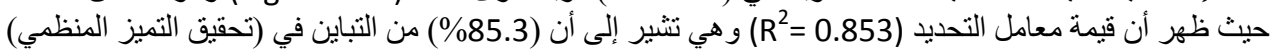

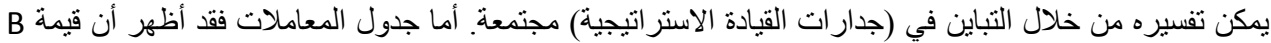

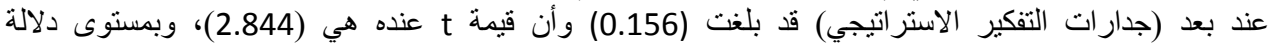

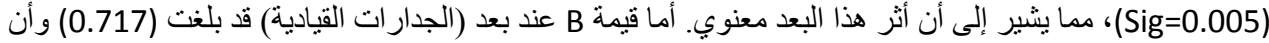

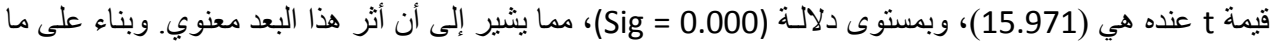

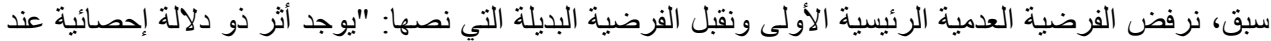

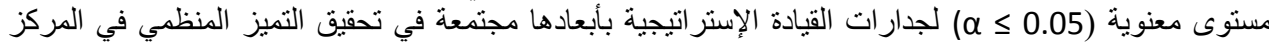

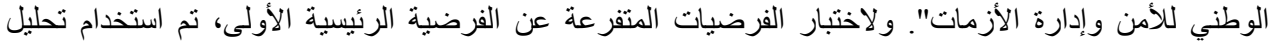

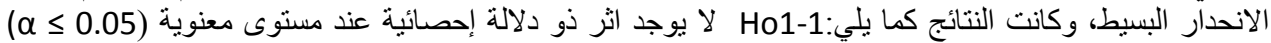

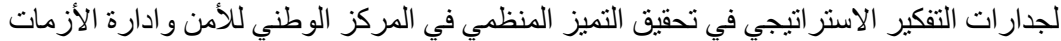

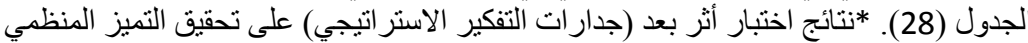

\begin{tabular}{|c|c|c|c|c|c|c|c|c|c|c|}
\hline & & $\begin{array}{l}\text { Coeffe } \\
\text { Coles }\end{array}$ & جدول & & & $\begin{array}{l}\text { ANOV } \\
\text { ANOتيلين }\end{array}$ & & $\begin{array}{r}\text { نموذج } \\
\text { Sum } \\
\text { Sur }\end{array}$ & $\begin{array}{l}\text { ملخص } \\
\text { del } \\
\text { nery }\end{array}$ & التنتير \\
\hline $\begin{array}{l}\text { Sig t* } \\
\text { مستوى الدلة }\end{array}$ & $\begin{array}{c}\text { T } \\
\text { المحسو }\end{array}$ & الخعياري & $B$ & البيان & $\begin{array}{c}\text { Sig } \\
\text { F* } \\
\text { الدلالةى }\end{array}$ & الحرية & المحسوبة F & $\begin{array}{c}r^{2} \\
\text { معامل }\end{array}$ & $\begin{array}{c}r \\
\text { معامل } \\
\text { الارتباط }\end{array}$ & \\
\hline 0.000 & 11.601 & 0.068 & 0.785 & جدارات التفكير & 0.000 & 1 & 134.574 & 0.533 & 0.730 & تحقيق \\
\hline & & & & ججي & & 118 & & & & مير \\
\hline & & & & & & 119 & & & & \\
\hline
\end{tabular}




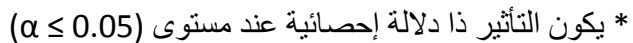

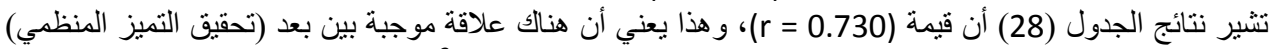

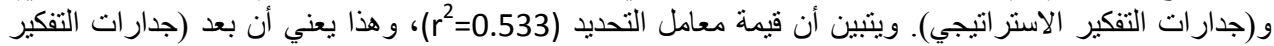

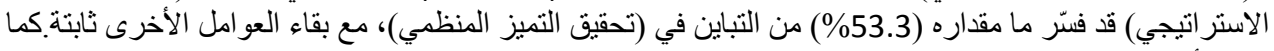

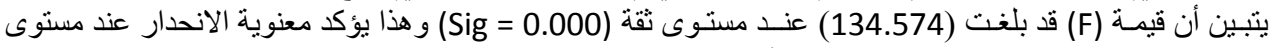

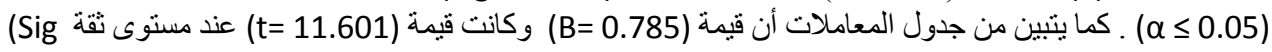

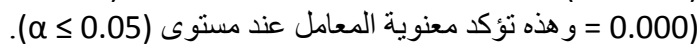

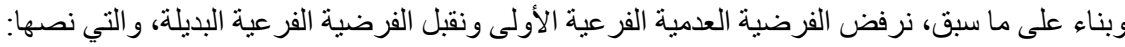
"يوجد اثر ذو دلالة إحصائية عند مستوى معنوية (1)

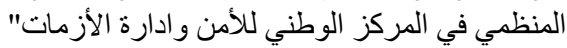

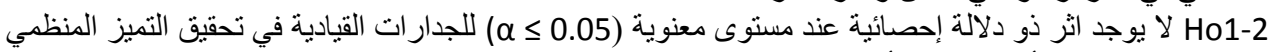
في المركز الوطني للأمن و ادارة الأزمات إنبات الجدول (29). *نتائج اختبار أثر بعد (الجدار ات القيادية) على تحقيق التميز المنظمي

\begin{tabular}{|c|c|c|c|c|c|c|c|c|c|c|}
\hline \multicolumn{5}{|c|}{ جدول المعاملات } & \multicolumn{3}{|c|}{$\begin{array}{c}\text { تحليل التباين } \\
\text { ANOVA }\end{array}$} & \multicolumn{2}{|c|}{$\begin{array}{c}\text { ملخص النموذج } \\
\text { Model } \\
\text { Summery } \\
\end{array}$} & \multirow[t]{2}{*}{ التابغير } \\
\hline $\begin{array}{l}\text { Sig t* } \\
\text { مستوى الدلة }\end{array}$ & $\begin{array}{c}\text { المحسو } \\
\end{array}$ & الخعياري & $B$ & البيان & $\begin{array}{l}\text { Sig } \\
\text { F* } \\
\text { الدلالةوى } \\
\end{array}$ & الحرية & المحسوبة & $\begin{array}{l}r^{2} \\
\text { معدادل }\end{array}$ & 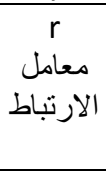 & \\
\hline \multirow[t]{3}{*}{0.000} & \multirow[t]{3}{*}{25.164} & \multirow[t]{3}{*}{0.032} & \multirow[t]{3}{*}{0.809} & \multirow{3}{*}{ القداراتية } & \multirow[t]{3}{*}{0.000} & 1 & \multirow[t]{3}{*}{633.248} & \multirow[t]{3}{*}{0.843} & \multirow[t]{3}{*}{0.918} & \multirow{3}{*}{ التحقيق } \\
\hline & & & & & & 118 & & & & \\
\hline & & & & & & 119 & & & & \\
\hline
\end{tabular}

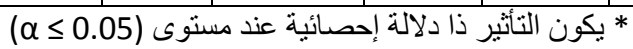

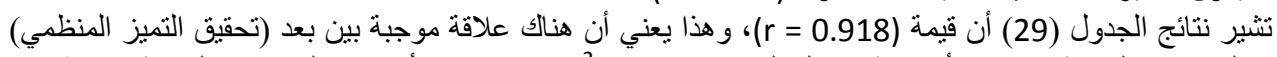

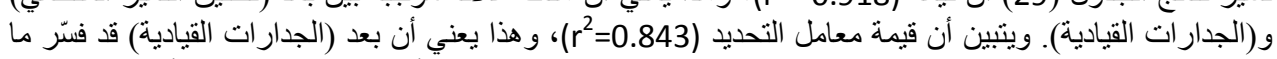

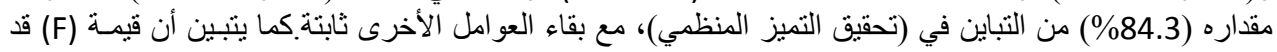

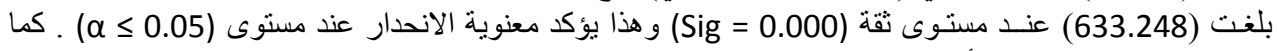

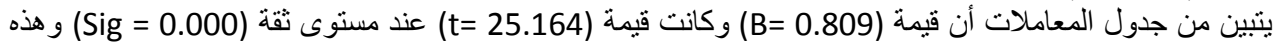

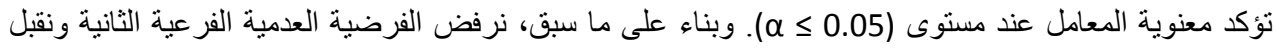

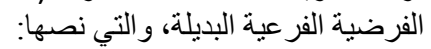

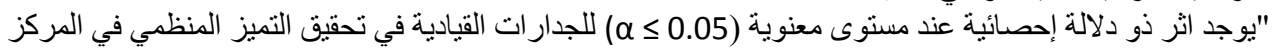

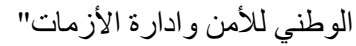
اختبار الفرضية الرئيسية الثانية

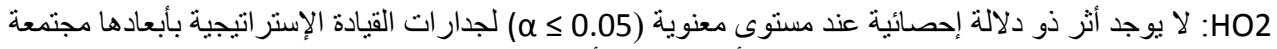

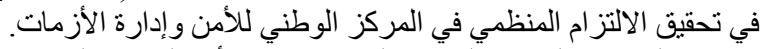

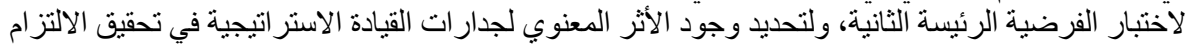

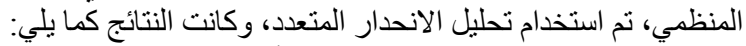
الجدول (30). *نتائج اختبار أثر جدارات القيادة الاستر اتيجية على تحقيق الالتز ام المنظمي

\begin{tabular}{|c|c|c|c|c|c|c|c|c|c|c|}
\hline \multicolumn{5}{|c|}{$\begin{array}{l}\text { جدول المعاملات } \\
\text { Coeffecient }\end{array}$} & \multicolumn{3}{|c|}{$\begin{array}{c}\text { تحليل التباين } \\
\text { ANOVA }\end{array}$} & \multicolumn{2}{|c|}{$\begin{array}{c}\text { ملنص النموذج } \\
\text { Model } \\
\text { Summery }\end{array}$} & \multirow[t]{2}{*}{ التابع } \\
\hline Sig $t$ & $\mathrm{~T}$ & المعياري & $B$ & البيان & Sig $\mathrm{F}$ & الحرجة & $\begin{array}{c}\text { F } \\
\text { المحسوبة }\end{array}$ & $\begin{array}{c}R^{2} \\
\text { معامل }\end{array}$ & $\begin{array}{c}\text { R } \\
\text { الارتبامل } \\
\text { المعلبا }\end{array}$ & \\
\hline 0.036 & 2.119 & 0.154 & 0.326 & جدار ات التفكير & 0.000 & 2 & 17.460 & 0.230 & 0.479 & تحقيق \\
\hline
\end{tabular}


Strategic Leadership Competencies and its Impact ....

\begin{tabular}{|c|c|c|c|c|c|c|}
\hline & & & & الاستر اتيجي & 117 & الالتز ام \\
\hline 0.023 & 2.312 & 0.126 & 0.291 & الجدار ات القيادية & 119 & \\
\hline
\end{tabular}

* يكون التأثير ذا دلالة إحصائية عند مستوى (a 0.05 (

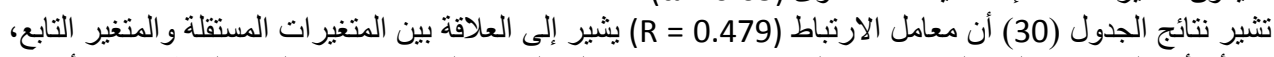

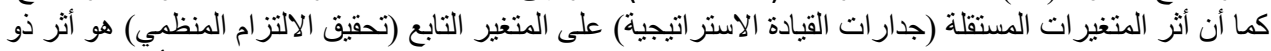

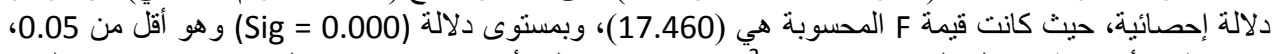

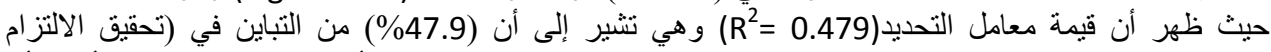

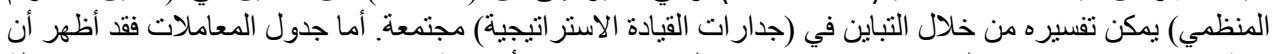

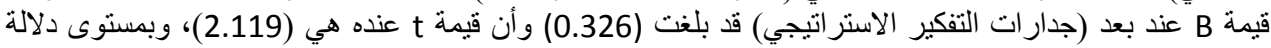

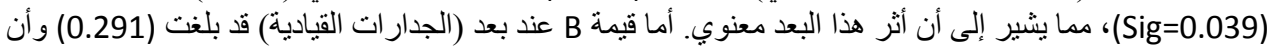

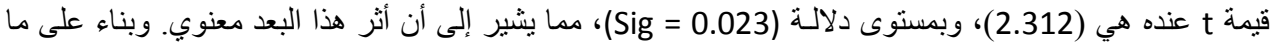

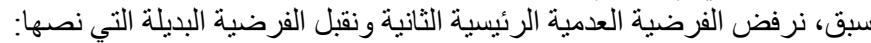

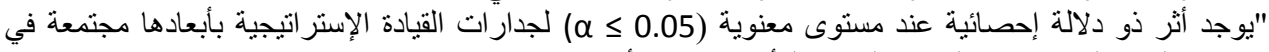

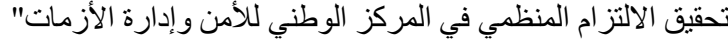

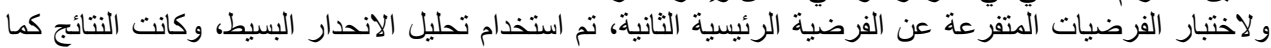

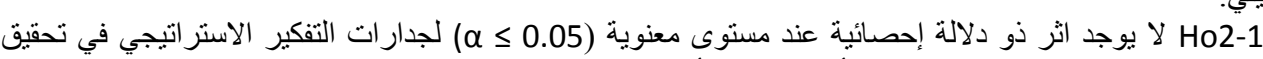

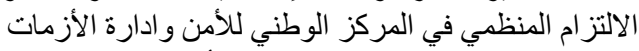
الجدول (31). *نتائج اختبار أثر بعد (جدار الثن الأ التفكير الاستر اتيجي) على تحقيق الالتزام المنظمي

\begin{tabular}{|c|c|c|c|c|c|c|c|c|c|c|}
\hline \multicolumn{5}{|c|}{ جدول المعاملات } & \multicolumn{3}{|c|}{$\begin{array}{c}\text { تحليل التباين } \\
\text { ANOVA }\end{array}$} & \multicolumn{2}{|c|}{$\begin{array}{c}\text { ملخص النموذج } \\
\text { Model } \\
\text { Summery }\end{array}$} & \multirow[t]{2}{*}{ التنتغير } \\
\hline $\begin{array}{l}\text { Sig t* } \\
\text { مستوى الدلة }\end{array}$ & $\begin{array}{c}T \\
\text { الحسبو }\end{array}$ & الخعياري & $B$ & البيان & $\begin{array}{c}\text { Sig } \\
\text { مستوى الدلالة } \\
\text { م* }\end{array}$ & $\begin{array}{c}\text { الحرجية } \\
\text { Df }\end{array}$ & $\begin{array}{c}\text { F } \\
\text { بحسو }\end{array}$ & $\begin{array}{c}r^{2} \\
\text { معدامل }\end{array}$ & معامل $\begin{array}{c}r \\
\text { الارتباط }\end{array}$ & \\
\hline \multirow[t]{3}{*}{0.000} & \multirow[t]{3}{*}{5.341} & \multirow[t]{3}{*}{0.109} & \multirow[t]{3}{*}{0.581} & \multirow{3}{*}{ جدارات التفكير } & \multirow[t]{3}{*}{0.000} & 1 & \multirow[t]{3}{*}{28.524} & \multirow[t]{3}{*}{0.195} & \multirow[t]{3}{*}{0.441} & \multirow{3}{*}{ الحنتيق المنيق } \\
\hline & & & & & & 118 & & & & \\
\hline & & & & & & 119 & & & & \\
\hline
\end{tabular}

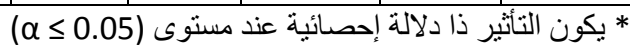

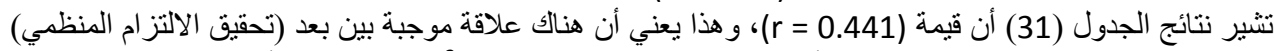

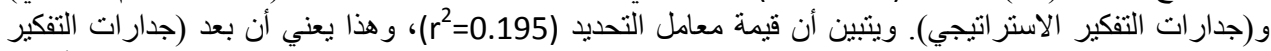

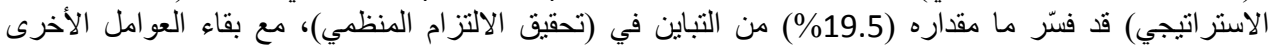

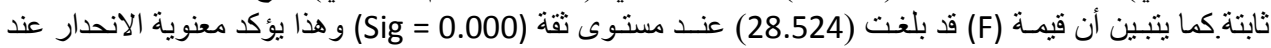

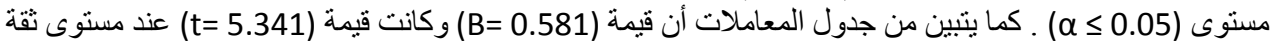

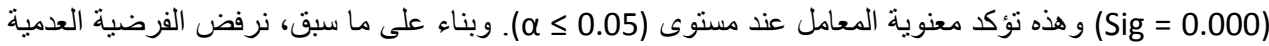

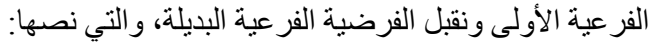

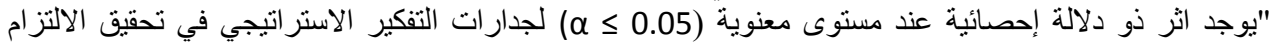

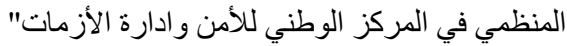

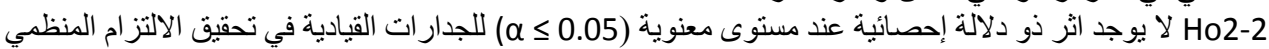
في المركز الوطني للأمن وادارة الأزمات لاتل 
Journal of Social Sciences (COES\&RJ-JSS), 8(1), pp.106-138

\begin{tabular}{|c|c|c|c|c|c|c|c|c|c|c|}
\hline \multicolumn{5}{|c|}{ جدول المعاملات 2 Coeffecient } & \multicolumn{3}{|c|}{$\begin{array}{c}\text { تحليل التباين } \\
\text { ANOVA }\end{array}$} & \multicolumn{2}{|c|}{$\begin{array}{c}\text { ملخص النموذج } \\
\text { Model } \\
\text { Summery }\end{array}$} & \multirow[t]{2}{*}{ التنابع } \\
\hline $\begin{array}{l}\text { Sig t* } \\
\text { الدنالةى }\end{array}$ & $\begin{array}{c}\text { T } \\
\text { المحسو } \\
\text { بة }\end{array}$ & الخعياري & B & البيان & $\begin{array}{l}\text { Sig } \\
\text { F* } \\
\text { الدلالةوى }\end{array}$ & الحرية & $\begin{array}{c}\text { المحسو } \\
\text { بة }\end{array}$ & $\begin{array}{l}r^{2} \\
\text { معامل }\end{array}$ & 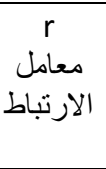 & \\
\hline \multirow[t]{3}{*}{0.000} & \multirow[t]{3}{*}{5.436} & \multirow[t]{3}{*}{0.089} & \multirow[t]{3}{*}{0.483} & \multirow{3}{*}{ القداراتية } & \multirow[t]{3}{*}{0.000} & 1 & \multirow[t]{3}{*}{29.554} & \multirow[t]{3}{*}{0.200} & \multirow[t]{3}{*}{0.448} & \multirow{3}{*}{ الحنتيق المنيق } \\
\hline & & & & & & 118 & & & & \\
\hline & & & & & & 119 & & & & \\
\hline
\end{tabular}

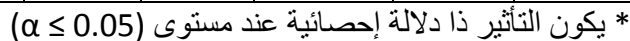

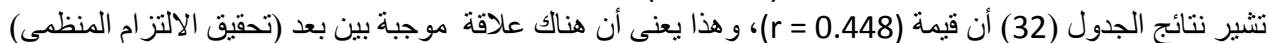

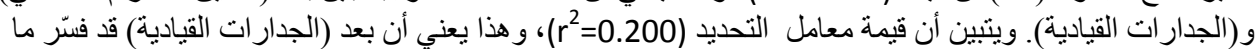

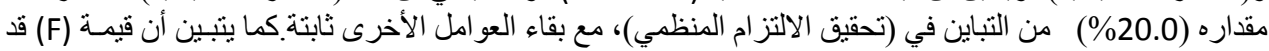

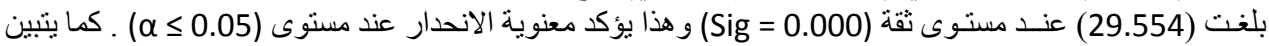

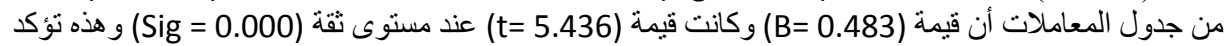

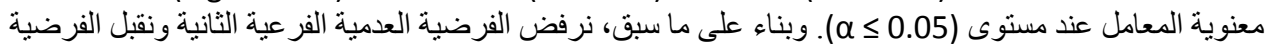

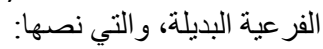
"يوجد اثر ذو دلالة إحصائية عند مستوى معنوية (2 0.05 م) للجدارات القيادية في تحقيق الالتزام المنظمي في

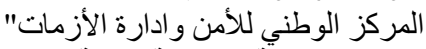

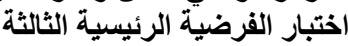

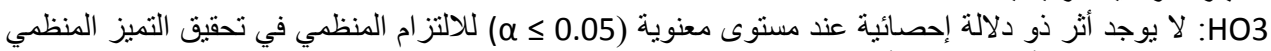

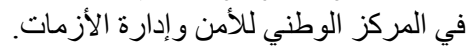

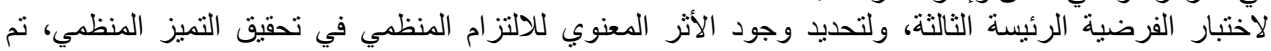

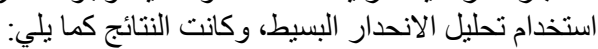

\begin{tabular}{|c|c|c|c|c|c|c|c|c|c|c|}
\hline \multicolumn{5}{|c|}{$\begin{array}{l}\text { جدول المعاملات } \\
\text { Coeffecient }\end{array}$} & \multicolumn{3}{|c|}{ تحليل التباين } & \multicolumn{2}{|c|}{$\begin{array}{c}\text { ملخص النموذج } \\
\text { Model } \\
\text { Summery }\end{array}$} & \multirow[t]{2}{*}{ التنابع } \\
\hline $\begin{array}{l}\text { Sig t* } \\
\text { مستوى }\end{array}$ & $\begin{array}{l}\text { المحسو } \\
\text { بة }\end{array}$ & المعياري & $B$ & البيان & 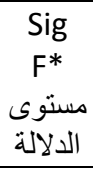 & الحرية & $\begin{array}{l}\text { المحسو } \\
\text { بة }\end{array}$ & 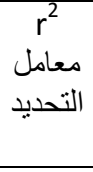 & $\begin{array}{c}\text { R } \\
\text { معامل } \\
\text { الارتباط }\end{array}$ & \\
\hline \multirow[t]{3}{*}{0.000} & \multirow[t]{3}{*}{5.690} & \multirow[t]{3}{*}{0.067} & \multirow[t]{3}{*}{0.379} & \multirow{3}{*}{ الالالنزمي } & \multirow[t]{3}{*}{0.000} & 1 & \multirow[t]{3}{*}{32.377} & \multirow[t]{3}{*}{0.215} & \multirow[t]{3}{*}{0.464} & \multirow{3}{*}{ التحقيق } \\
\hline & & & & & & 118 & & & & \\
\hline & & & & & & 119 & & & & \\
\hline
\end{tabular}

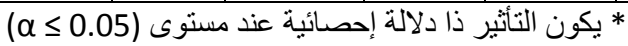

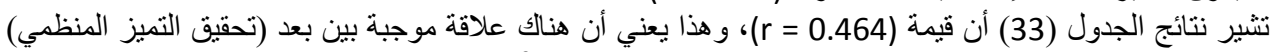

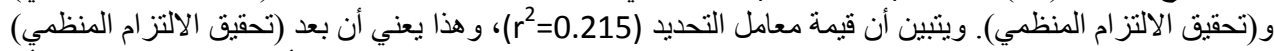

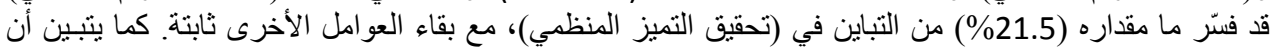

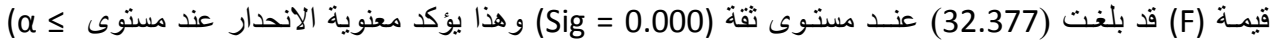

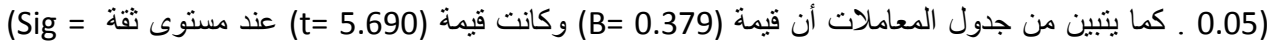

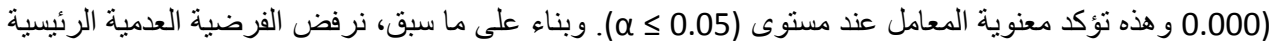
ونقبل الفرضية الفر عية البديلة، و التي نصها: 


\section{Strategic Leadership Competencies and its Impact ....}

"يوجد أثر ذو دلالة إحصائية عند مسنوى معنوية (0.05 a 0 ل للالتز ام المنظمي في تحقيق التميز المنظمي في المركز

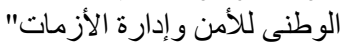

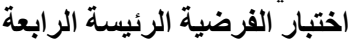

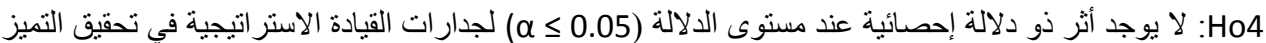

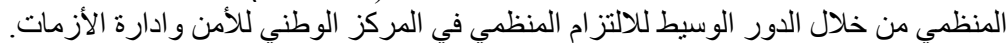

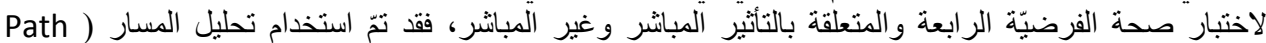

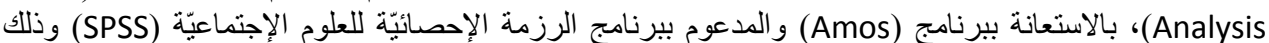

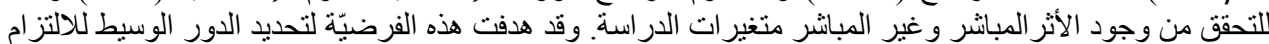

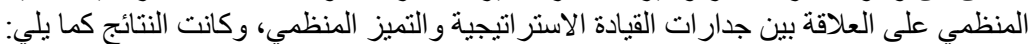

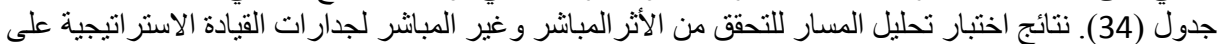

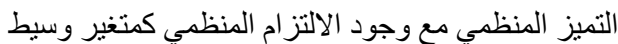

\begin{tabular}{|c|c|c|c|c|c|c|}
\hline \multicolumn{7}{|c|}{ ملائمة النموذج Model Fit } \\
\hline $\begin{array}{c}\text { Sig } \\
\text { مستوى الدلة }\end{array}$ & 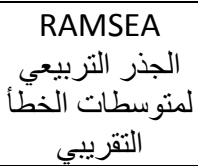 & $\begin{array}{c}\text { مؤشر المواعمة } \\
\text { المقارن }\end{array}$ & 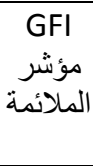 & 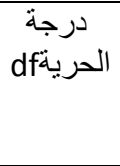 & $\begin{array}{c}\text { Chi }^{2} \\
\text { المحسوبة }\end{array}$ & البيان \\
\hline 0.000 & 0.077 & 0.929 & 0.943 & 2 & 9.589 & التنظيز \\
\hline
\end{tabular}

أظهرت نتائج التحليل الاحصائي في الجدول (34) أنّ قيمة (Chi

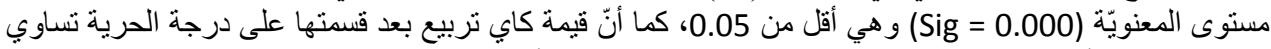

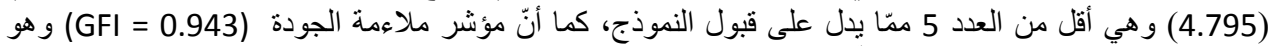

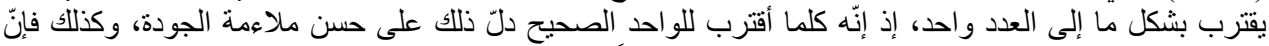

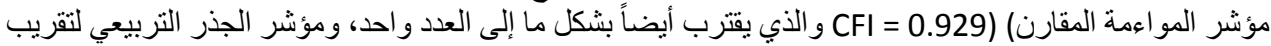

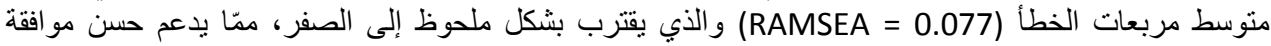
النموذج.

جدول (35). معاملات الأثر المباثر و غير المباثر للفرضيّة الرئيسيّة الرابعة H04

\begin{tabular}{|c|c|c|c|c|c|}
\hline \multicolumn{6}{|c|}{ المعاملات Estimates } \\
\hline مستوى (مست & قيمة معامل & 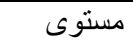 & النسبة & \multirow{3}{*}{\multicolumn{2}{|c|}{ قيميم معاملات التأثيّر المباشر }} \\
\hline 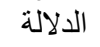 & التأثير غير & Sig الدلالة & C.R.الحرجة & & \\
\hline Sig & المباثر & & & & \\
\hline 0.006 & 0.178 & 0.002 & 3.150 & 0.290 & جدارات التفكير الاستر اتيجي ـ الالتز ام المنظمي \\
\hline 0.018 & 0.604 & 0.000 & 8.133 & 0.986 & الجدار ات القيادية ـ الالتز ام المنظمي \\
\hline & & 0.000 & 7.669 & 0.613 & الالتز ام المنظمي ـ التمبز المنظمي \\
\hline
\end{tabular}

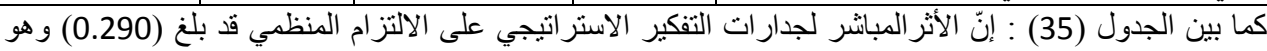

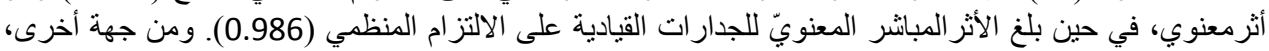

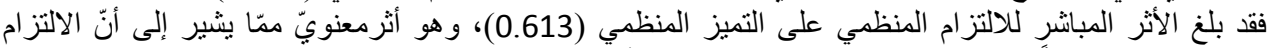

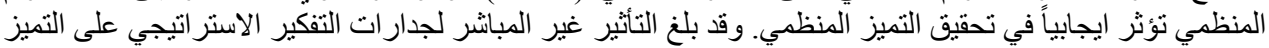

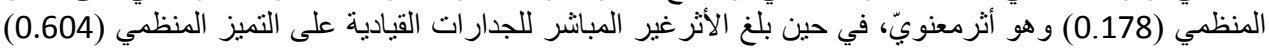

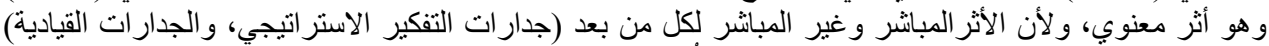

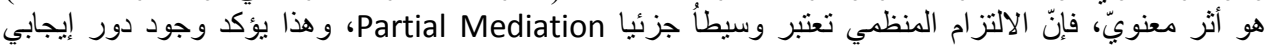

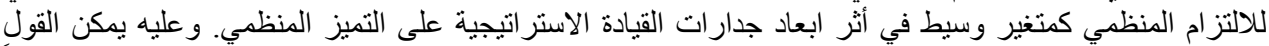

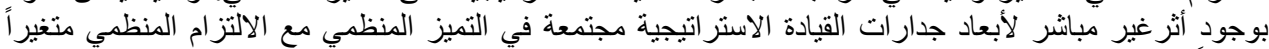

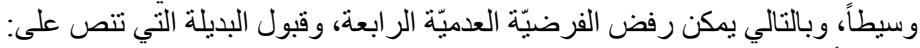

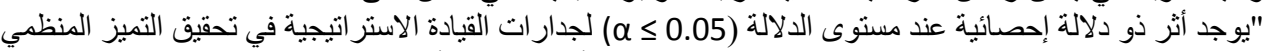
من خلال الدور الوسيط للالتز ام المنظمي في المركز الوطني للأمن وادارة الأزمات التادئ 


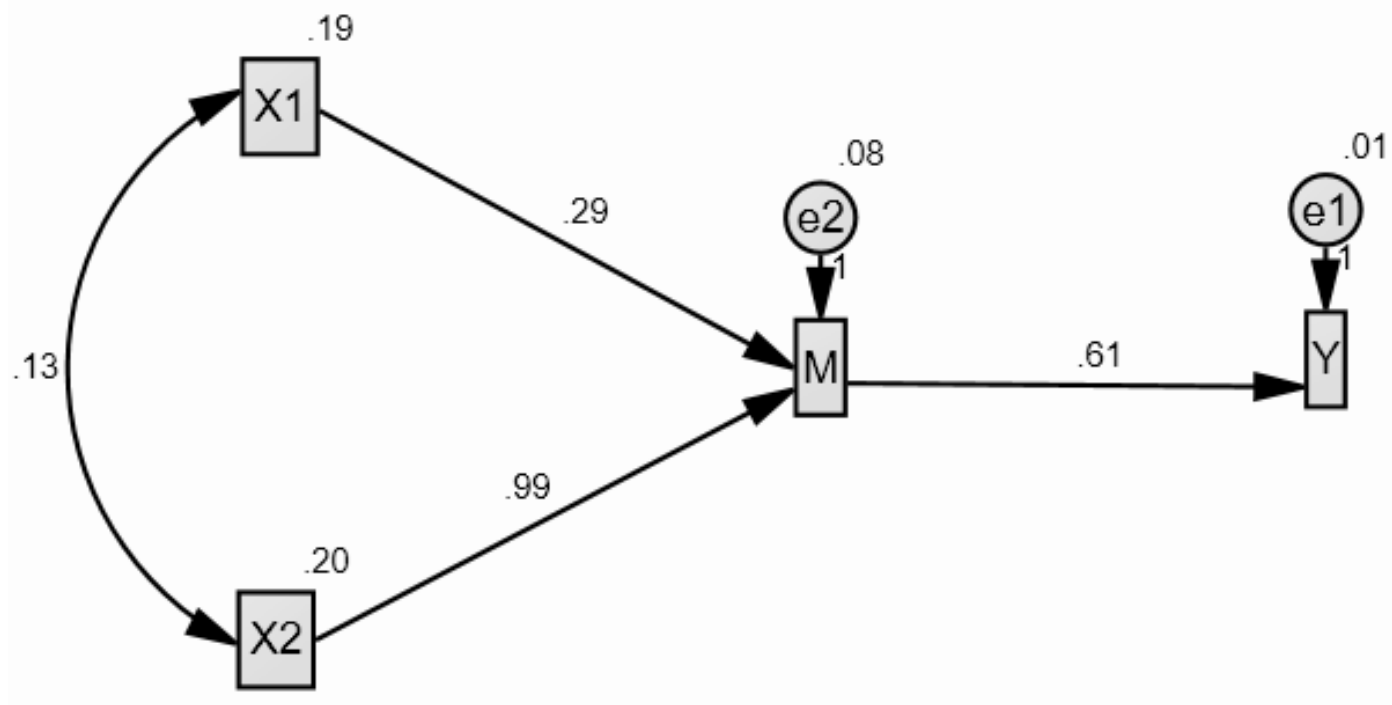

X1 جد: جدار X الشكل رقم (2). نتائج إختبار الفرضيّة الرئيسيّة الرابعة

4. النتائج والتوصيات والمقترحات

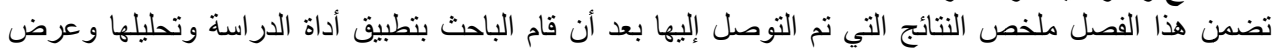

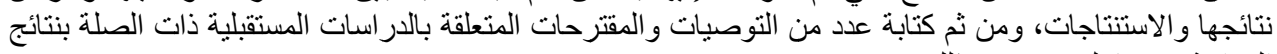

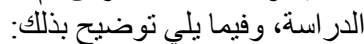

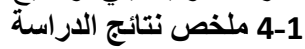

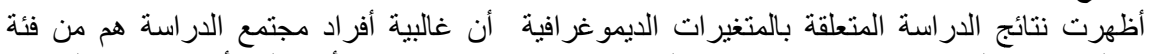

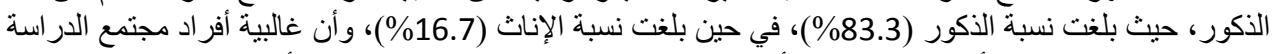

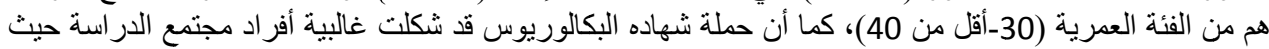

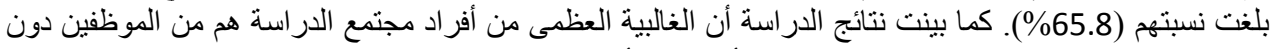

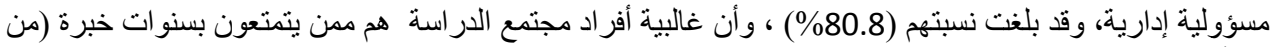

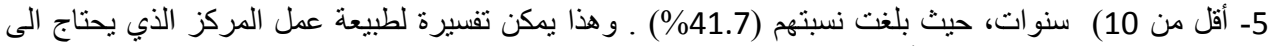
الجهد الكثير الذي يتخملة الذكور أكثر من الاناث.

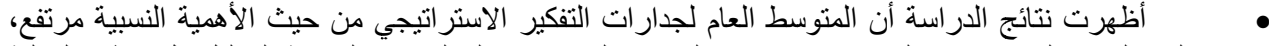

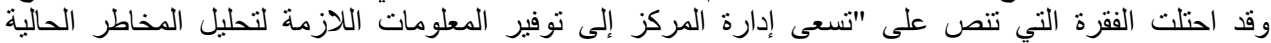

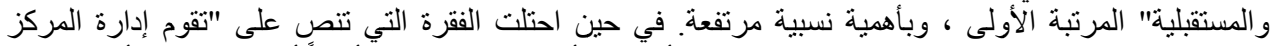

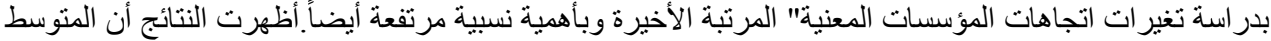

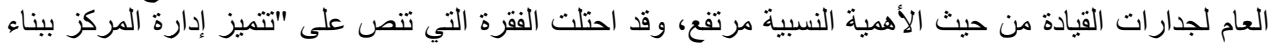

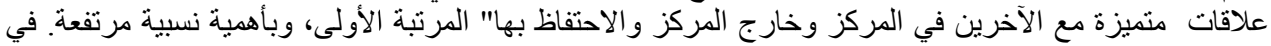

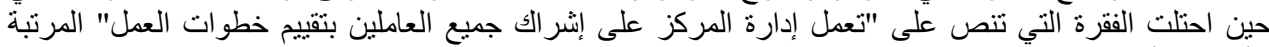
الأخيرة وبأهمية نسبية متوسطة.

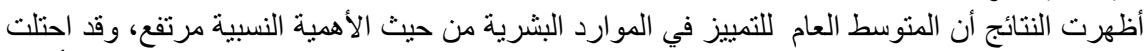

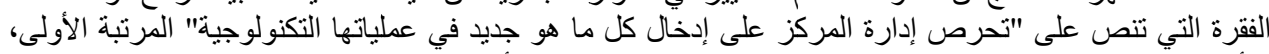

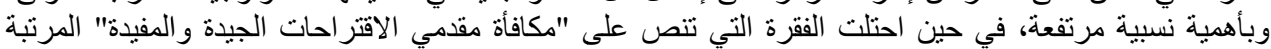
الأخيرة وبأهمية نسبية مرتفية مرنعة فين. 


\section{Strategic Leadership Competencies and its Impact ....}

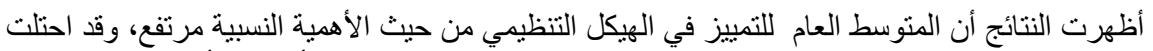

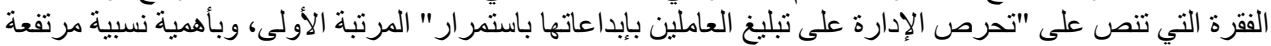

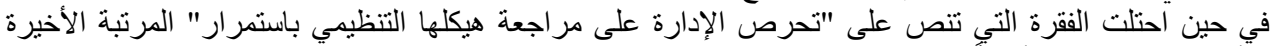

وبأهمية نسبية مرتفعة أيضاً.

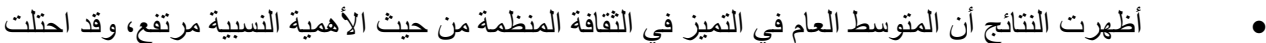

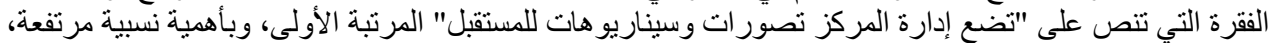

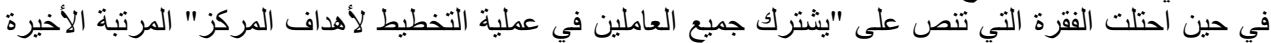

وبأهمية نسبية منوسطة.

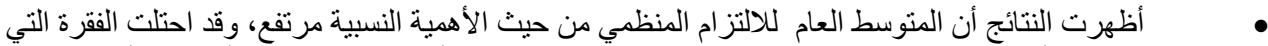

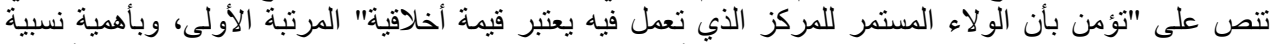

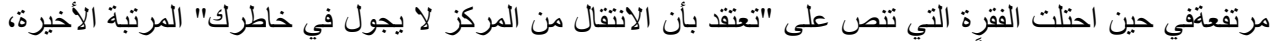

وبأهية نسبية مرتفعة أيضاً.

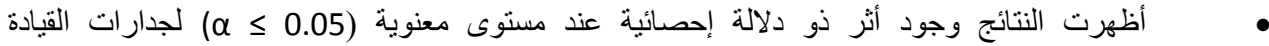

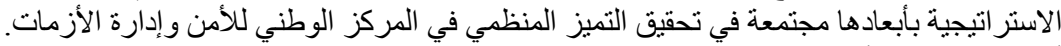

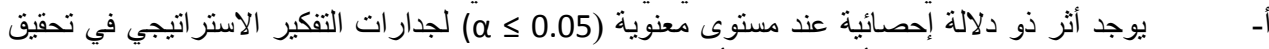

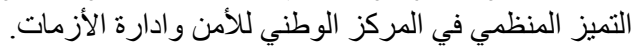

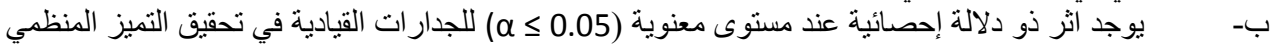
في المركز الوطني للأمن وادارة الأزمات دالئ.

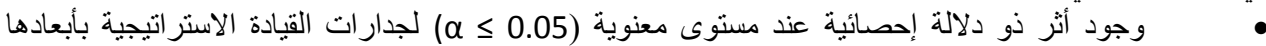
مجتمعة في تحقيق الالتز ام المنظمي في المركز الوطنة الوطني للأمن و إدارة الأزمات

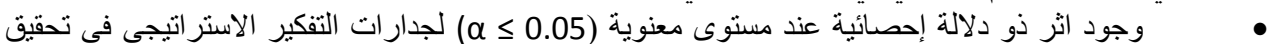

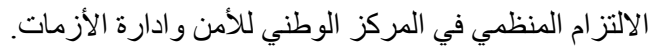

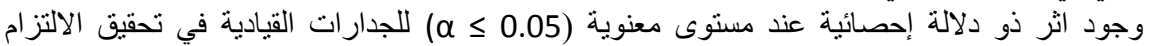
المنظمي في المركز الوطني للأمن و ادارة الأزمات.

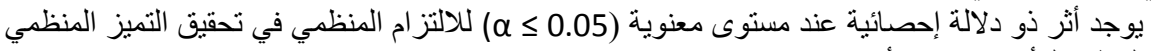
في المركز الوطني للأمن و إدارة الأزمات إحلة

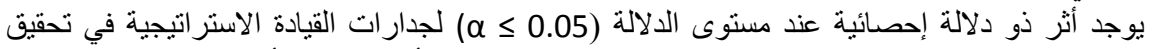

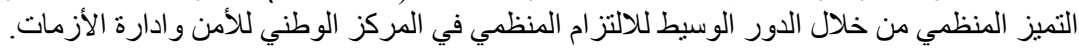

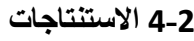
من خلال النتائج التي تم ذكر ها في الدراسة، فانه يمكننا التوصل الى التى عدد من الاستنتاجات:

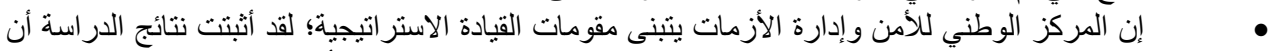

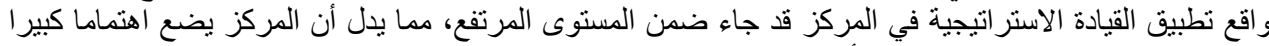

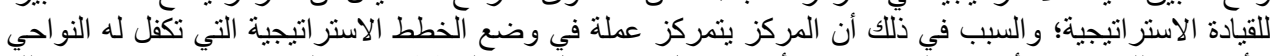

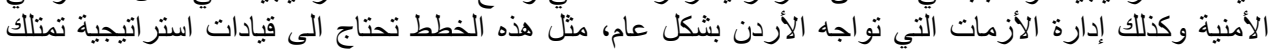

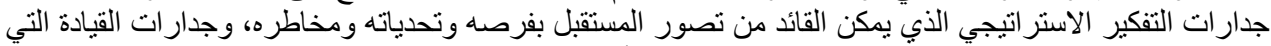

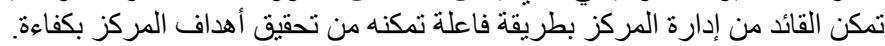

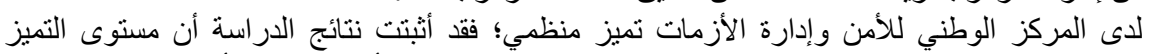

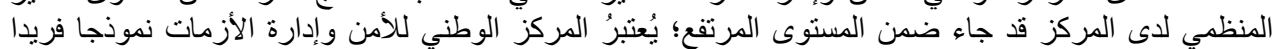

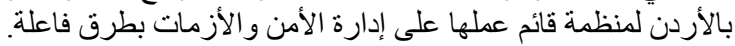

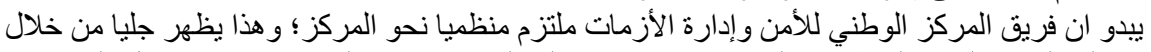

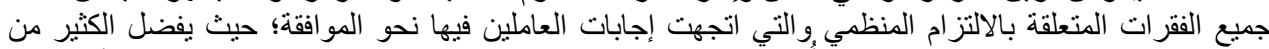

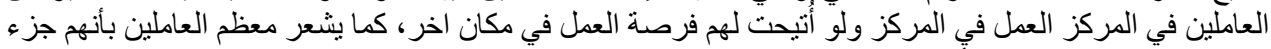

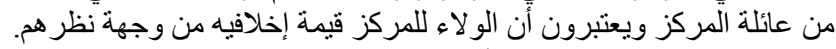

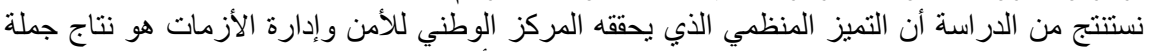

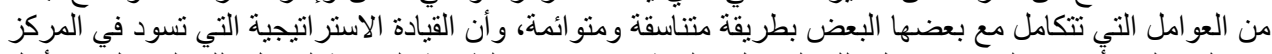

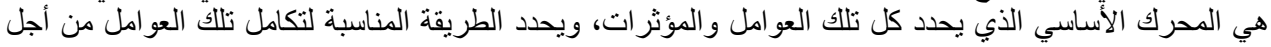

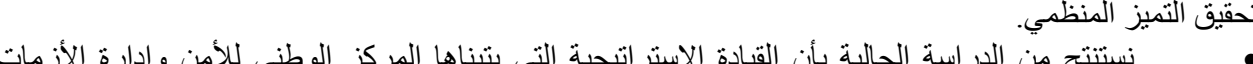

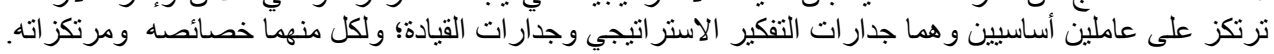




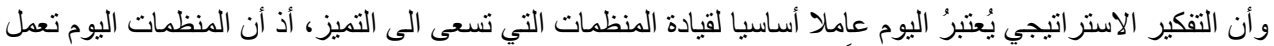

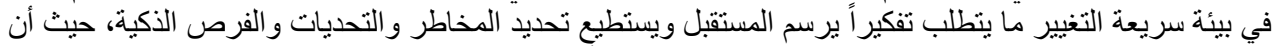

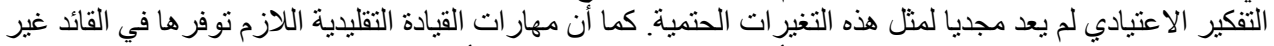

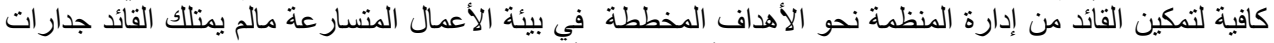

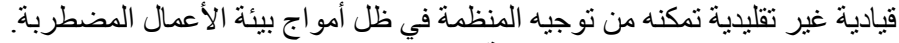
4-3 التوصيات والدراسات المستقبلية

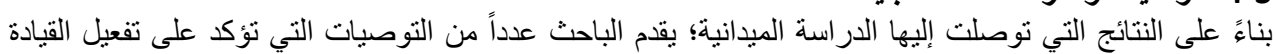

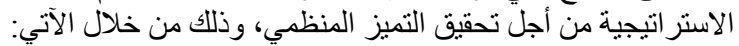

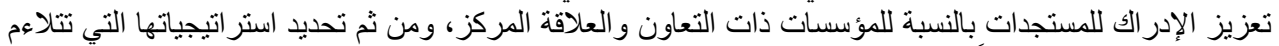

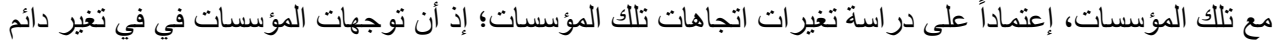
ومستمر نتيجة للتغير المستمر في البيئة العامة.

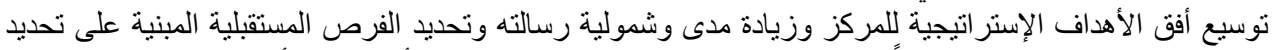

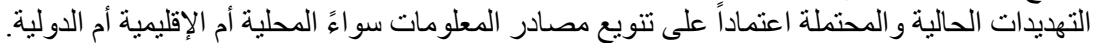

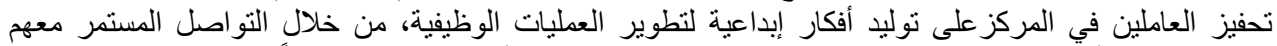

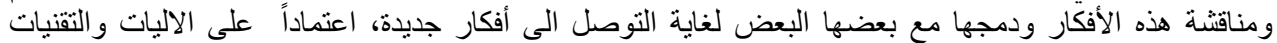

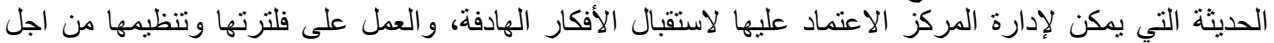

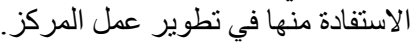

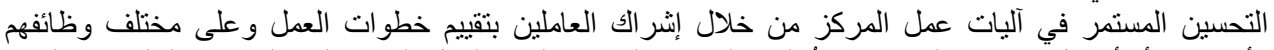

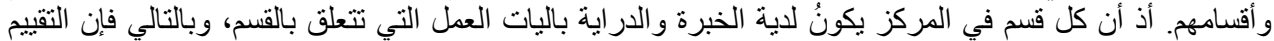

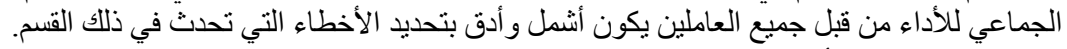

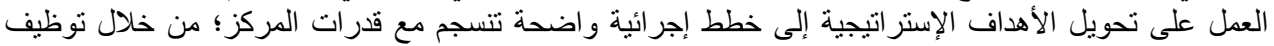

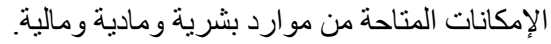

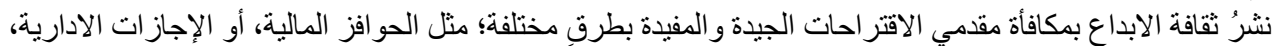

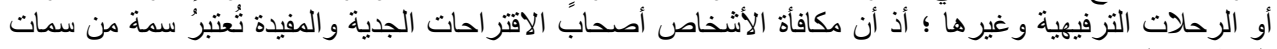

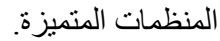

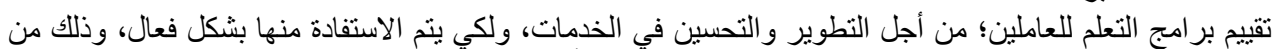

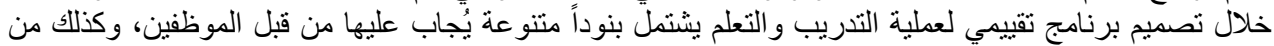

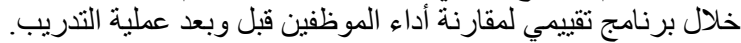

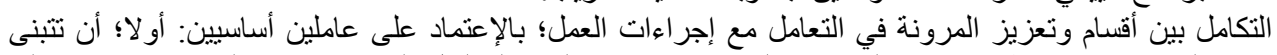

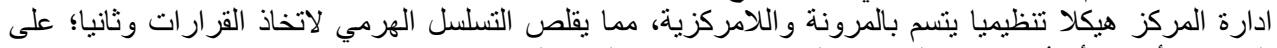

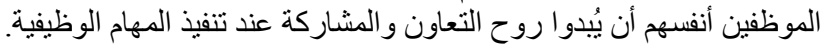

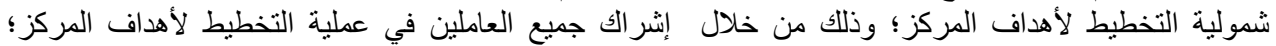

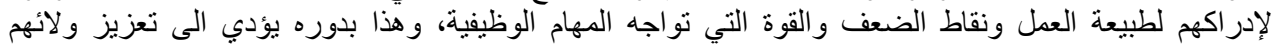

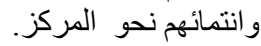
تفعيل دور عمل الفريق بشكل أكبر داخل المركز، وذللك من خلال تشكيل فرق عمل قائمة على التتوع من الأقسام

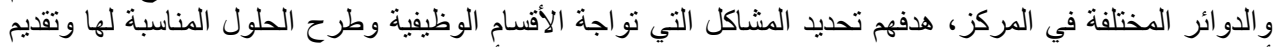

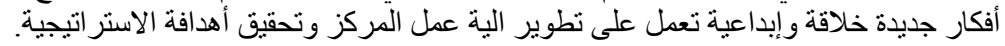

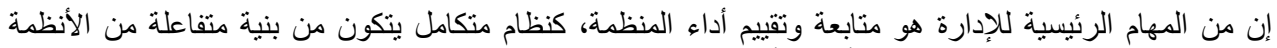

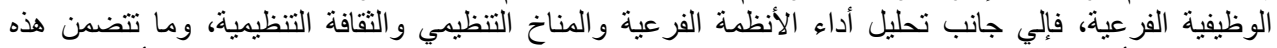

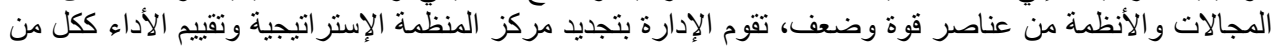

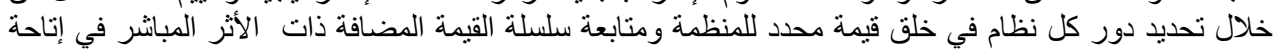

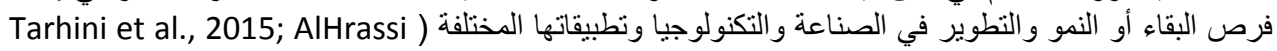
et al., 2016; Masa'deh et al., 2018a, b, c; Yassien \& Mufleh, 2017; Alenezi et al., 2017; Alkandari et al., 2017; Altamony \& Gharaibeh, 2017; Khwaldeh et al., 2017; Mikkawi \& AlLozi, 2017 (Lot)، وما آلت إليه التطورات التكنولوجية في القرن الواحد والعشرين والضغوطات التي تمخضت عن

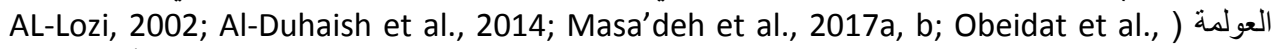
(2013, 2016, 2017; Alananzeh et al., 2018; Abualoush et al., 2018a, b; Khalayleh et al., 2017; Al-) اصبح يستخدم أساليب حديثة ومنطورة في مجال الإدارة والقرار الإداري (AL-Syaidh et al., 2014, 2016; (dalahmeh et al., 2018 
فسار عت إلى تطوير نظم المعلومات الإدارية (Darawsheh et al., 2016; Masa'deh et al., 2015a, b) Masa'deh, et al., 2008; Shannak \& Obeidat, 2012; ) والخدمات الالكترونية بمختلف القطاعات Karajeh \& Maqableh, 2014; Maqableh \& Karajeh, 2014; Al-Dmour et al., 2015; Almajali \& Maqableh, 2015; Maqableh \& Mohammed, 2015; Maqableh et al., 2015; Masa'deh, 2016; Tarhini et al., 2016, 2017a, 2017b; Almajali \& Al-Dmour, 2016; Almajali \& Tarhini, 2016; Almajali et al., 2016a, b; Aldmour et al., 2017; Obeidat et al., 2017, 2019; Tarhini et (al., 2018; Masa'deh, et al., 2019a, b; Al-Dmour et al., 2019 و الدفاهيم التي تتخذ بها القرارات الإدارية ولتسهم في التنظيم و التخطيط و الرقابة الإدارية (

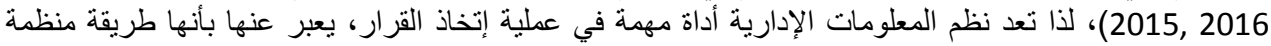

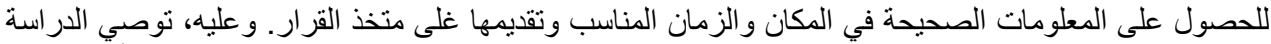

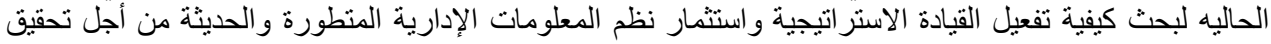

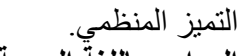
المراجع باللغةٍ العربية

بور اس، (2013). دور القيادة الادارية في تنمية الثقافة التنظيمية لاى العاملين. رسالة ماجستير منشور . جامعة ـ محمد نيضر بسكرة.

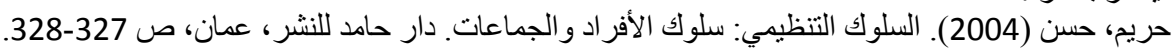

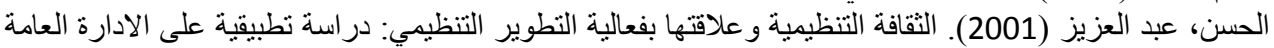

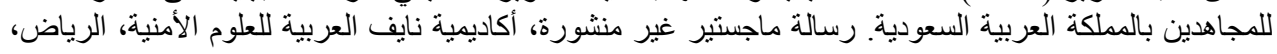

الحيان، فها (2016)، دور تمكين العاملين في تحسين الأداء: دراسة ميدانية مقارنة بين مؤسسات التعليم العالي العامة

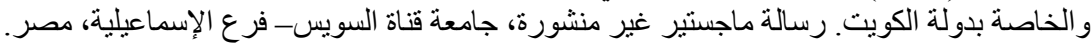

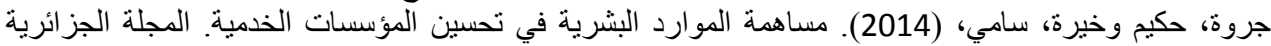

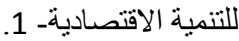

المبيضين، أنس (2009). دور القيادة الاستر اتيجية في تعزيز القدرة التنافسية: دراسة تطبيقية على الملكية الأردنية.

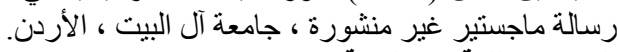

المراجع باللفة الانجليزية

\section{References}

Abualoush, S., Bataineh, K., \& Alrowwad, A. (2018a). The Role of Knowledge Management Process and Intellectual Capital as Intermediary Variables between Knowledge Management Infrastructure and Organization Performance. Interdisciplinary Journal of Information, Knowledge, and Management, 13, 279-309.

Abualoush, S., Obeidat, B., \& Tarhini, A. (2018b). The Role of Employees' Empowerment as an Intermediary Variable between Knowledge Management and Information Systems on Employees' Performance. VINE Journal of Information and Knowledge Management Systems, 48(2), 217-237.

Alananzeh, O., Jawabreh, O., Al-Mahmoud, A., \& Hamada, R. (2018). The Impact of Customer Relationship Management on Tourist Satisfaction: The Case of Radisson Blue Resort in Aqaba City. Journal of Environmental Management and Tourism, 2(26), 227240.

Al-dalahmeh, M., Khalaf, R., \& Obeidat, B. (2018). The Effect of Employee Engagement on Organizational Performance via the Mediating Role of Job Satisfaction: The Case of IT Employees in Jordanian Banking Sector. Modern Applied Science, 12(6), 17-43. 
Al-Dmour, R., Al Haj Dawood, E., Al-Dmour, H., \& Masa'deh, R. (2019). The Effect of Customer Lifestyle Patterns on the Use of Mobile Banking Applications in Jordan. Int. J. Electronic Marketing and Retailing, Forthcoming.

Aldmour, R., Masa'deh, R., \& Obeidat, B. (2017). Factors Influencing the Adoption and Implementation of HRIS Applications: Are they Similar. International Journal of Business Innovation and Research, 14(2), 139-167.

Al-Dmour, R, Obeidat, B., \& Almajali, D. (2015). The Practice of HRIS Applications in Business Organizations in Jordan: An Empirical Study. 4th Scientific \& Research Conference on New Trends in Business, Management and Social Sciences (COES\&RJTK15/1).

Al-Duhaish, A., Alshurideh, M., \& Al-Zu'bi, Z. (2014). The Impact of the Basic Reference Group Usage on the Purchasing Decision of Clothes (A Field Study of Saudi Youth in Riyadh City). Dirasat: Administrative, 41(2), 205-221.

Alenezi, H., Tarhini, A., Alalwan, A., \& Al-Qirim, N. (2017). Factors Affecting the Adoption of E-Government in Kuwait: A Qualitative Study. Electronic Journal of e-Government, 15(2), 84-102.

AlHarrasi, J., \& AL-Lozi, M. (2015). The Role of Innovation Management and Technological Innovation on Organizational Effectiveness. 4th Scientific \& Research Conference on New Trends in Business, Management and Social Sciences (COES\&RJTK15/1), Istanbul, Turkey.

AlHarrasi, J., \& AL-Lozi, M. (2016). The Role of Innovation Management and Technological Innovation on Organizational Effectiveness: A Theoretical Model. Journal of Social Sciences (COES\&RJ-JSS), 5(1), 80-95.

AlHrassi, J., Al-Lozi, M., \& Irtaimeh, H. (2016). The Impact of Management Innovation and Technological Innovation on Organizational Effectiveness: An Empirical Study from Managerial Staff Perspective in Sultan Qaboos University. Journal of Social Sciences (COES\&RJ-JSS), 5(3), 309-339.

Alkandari, A., Masa'deh, R., \& Al-Lozi, M. (2017). Knowledge Management and its Role on Organizational Crisis Management: A Literature Review. Journal of Social Sciences (COES\&RJ-JSS), 6(4), 833-850.

AL-Lozi, M. (2002). Total Quality Management in the Civil Service Institutions in Jordan. Mu'tah: Humanities and Social Sciences Series, 18(4), 151-185.

Almajali, D., \& Al-Dmour, R. (2016). The Role of Information Technology in Motivating Students to Accept E-Learning Adoption in Universities: A Case Study in Jordanian Universities. Journal of Business \& Management (COES\&RJ-JBM), 4(1), 36-46. 
Almajali, D., \& Maqableh, M. (2015). Assessing the Digital Divide Status of the Jordanian Telecentre. International Journal of Communications, Network and System Sciences, 8(11), 428-439.

Almajali, D., \& Tarhini, A. (2016). Antecedents of ERP Systems Implementation Success: A Study on Jordanian Healthcare Sector. Journal of Enterprise Information Management, 29(4), 549-565.

Almajali, D., Mansour, K., \& Maqableh, M. (2016a). The Impact of Electronic Supply Chain Management Usage on Firm's Performance. International Journal of Communications, Network and System Sciences, 9(6), 280-293.

Almajali, D., Masa'deh, R., \& Al-Lozi, M. (2016b). Determinants of the Actual Use of ELearning Systems: An Empirical Study on Zarqa University in Jordan. Journal of Social Sciences (COES\&RJ-JSS), 5(2), 172-200.

AL-Syaidh, N., Al- Lozi, M., \& AlHarrasi, J. (2016). Transformational Leadership and its Role on the Effectiveness of Employees' Behavior: A Theoretical Study. Journal of Business \& Management (COES\&RJ-JBM), 4(1), 14-35.

AL-Syaidh, N., Masa'deh, R., \& Al-Zu'bi, Z. (2014). Transformational Leadership and its Impact on the Effectiveness of Employees' Behavior in the Public and Private Jordanian Hospitals. Jordan Journal of Business Administration, 11(1), 23-57.

Altamony, H., \& Gharaibeh, A. (2017). The Role of Academic Researcher to Mintzberg's Managerial Roles. International Journal of Business Management and Economic Research, 8(2), 920-925.

Aslan, S., \& Diken, A. (2011). Investigation of the Effects of Strategic Leadership on Strategic Change and Innovativeness of SMEs in a Perceived Environmental Uncertainty. Procedia-Social and Behavioral Sciences, 24, 627-642.

Azbari, M., Akbari, M., \& Shaijani, M. (2015). The Effect of Strategic Leadership and Empowerment on Job Satisfaction of the Employees of University of Guilan. International Journal of Organizational Leadership, 4, 453-464.

Bagg, A. (2001). Strategic Thinking must Precede Strategic Planning. www.corporaiteimags.com.

Berke, D., Kossler, M.E., \& Wakefield (2008). Developing Leadership Talent. San Fransisco, CA: Pfeiffer.

Chen, C.J., \& Huang, J.W. (2007). How Organizational Climate and Structure Affect Knowledge Management: The Social Interaction Perspective. International Journal of Information Management, 27, 104-118.

Clark, J., \& Armit, K. (2010). Leadership Competency for Doctors: A Framework. Leadership in Health Services, 23(2), 115-129. 
Darawsheh, S., ALshaar, A., \& AL-Lozi, M. (2016). The Degree of Heads of Departments at the University of Dammam to Practice Transformational Leadership style from the Point of View of the Faculty Members. Journal of Social Sciences (COES\&RJ-JSS), 5(1), 56-79.

Hamel, G., \& Prahalad (2005). Strategic Intent, the High Performance Organization- The Best of HBR, Harvad Business Review.

Haniya, S. (2017). Strategic Leadership Development: Simplified with Bloom's Taxonomy. Industrial and Commercial Training, 49(1), 40-47.

Hitt, M.A., \& Ireland, R.D. (2005). Achieving and Maintaining Strategic Competitiveness in the 21st Century: The Role of Strategic Leadership. Management, 19(4), 63-77.

Irtaimeh, H. (2017). Impact of Strategic Leadership Competencies on Enhancing Core Competencies in Organizations "Applied Study on Almanaseer Group". International Journal of Advanced Research, 5(2), 2528-2538.

Karajeh, H., \& Maqableh, M. (2014). Security of Cloud Computing Environment. The 23rd IBIMA Conference on Vision 2020: Sustainable Growth, Economic Development, and Global Competitiveness, USA, 2202-2215.

Khalayleh, W., Masa'deh, R., \& Al-Lozi, M. (2017). Administrative Empowerment and its Role on the Work Teams Performance: A Literature Review. Journal of Social Sciences (COES\&RJ-JSS), 6(4), 851-868.

Khwaldeh, S., Al-Hadid, I., Masa'deh, R., \& Alrowwad, A. (2017). The Association between E-Services Web Portals Information Quality and ICT Competence in the Jordanian Universities. Asian Social Science, 13(3), 156-169.

León, M., \& Martínez, J. (2011). The Influence of Organizational Structure on Organizational Learning. International Journal of Manpower, 32(5/6), 537-566.

Maqableh, M., \& Mohammed, A. (2015). The Acceptance and Use of Computer based Assessment in Higher Education. Journal of Software Engineering and Applications, 8(10), 557.

Maqableh, M., \& Karajeh, H. (2014). Job Scheduling for Cloud Computing using Neural Networks. Communications and Network, 6(3), 191-200.

Maqableh, M., Rajab, L., Quteshat, W., Khatib, T., \& Karajeh, H. (2015). The Impact of Social Media Networks Websites Usage on Students' Academic Performance. Communications and Network, 7(4), 159-171.

Masa'deh, R. (2016). The Role of Knowledge Management Infrastructure in Enhancing Job Satisfaction at Aqaba Five Star Hotels in Jordan. Communications and Network, 8(4), 219-240. 
Masa'deh, R., Alananzeh, O., Algiatheen, N., Ryati, R., Albayyari, R., \& Tarhini, A. (2017a). Employee's Perception of Implementing Green Supply Chain Management on Hotel's Economic and Operational Performance. Journal of Hospitality and Tourism Technology, 8(3), 395-416.

Masa'deh, R., Shannak, R., Maqableh, M., \& Tarhini, A. (2017b). The Impact of Knowledge Management on Job Performance in Higher Education: The Case of the University of Jordan. Journal of Enterprise Information Management, 30(2), 244-262.

Masa'deh, R., Alananzeh, O., Algudah, O., \& Tarhini, A. (2018a). The Effect of Promotional Mix on Hotel Performance during the Political Crisis in the Middle East. Journal of Hospitality and Tourism Technology, 9(1), 33-49.

Masa'deh, R., Alrowwad, A., Alkhalafat, F., Obeidat, B., \& Abualoush, S. (2018b). The Role of Corporate Social Responsibility in Enhancing Firm Performance from the Perspective of IT Employees in Jordanian Banking Sector: The Mediating Effect of Transformational Leadership. Modern Applied Science, 12(7), 1-26.

Masa'deh, R., Al-Henzab, J., Tarhini, A., \& Obeidat, B. (2018c). The Associations among Market Orientation, Technology Orientation, Entrepreneurial Orientation and Organizational Performance. Benchmarking: An International Journal, 25(8), 3117-3142.

Masa'deh, R., Hunaiti, Z., \& Bani Yaseen, A. (2008). An Integrative Model Linking ITBusiness Strategic Alignment and Firm Performance: The Mediating Role of Pursuing Innovation and Knowledge Management Strategies. Communications of the International Business Information Management Association (IBIMA) Journal.

Masa'deh, R., Gharaibeh, A., Tarhini, A., \& Obeidat, O. (2015a). Knowledge Sharing Capability: A Literature Review. 4th Scientific \& Research Conference on New Trends in Business, Management and Social Sciences (COES\&RJ-TK15/1), Istanbul, Turkey.

Masa'deh, R., Obeidat, B., Zyod, D., \& Gharaibeh, A. (2015b). The Associations among Transformational Leadership, Transactional Leadership, Knowledge Sharing, Job Performance, and Firm Performance: A Theoretical Model. Journal of Social Sciences (COES\&RJ-JSS), 4(2), 848-866.

Masa'deh, R., Almajali, D., Alrowwad, A., \& Obeidat, B. (2019a). The Role of Knowledge Management Infrastructure in Enhancing Job Satisfaction: A Developing Country Perspective. Interdisciplinary Journal of Information, Knowledge, and Management. Forthcoming.

Masa'deh, R., Obeidat, B., Maqableh, M., \& Shah, M. (2019b). The Impact of Business Intelligence Systems on an Organization's Effectiveness: The Role of Metadata Quality from a Developing Country's View. International Journal of Hospitality \& Tourism Administration, Forthcoming. 
Mikkawi, B., \& Al-Lozi, M. (2017). The Impact of Knowledge Management Infrastructure on Academic Staff Effectiveness: An Empirical Study at The University of Jordan. Jordan Journal of Business Administration, 13(1), 95-127.

Mills, K., \& Ungson, R. (2003). Reassessing the Limits of Structural Empowerment: Organizational Constitution and Trust as Controls. Academy of Management Review, 28, 143-153.

Müller, R., \& Turner, R. (2010). Attitudes and Leadership Competences for Project Success. Baltic Journal of Management, 5(3), 307-329.

Nuntamanop, P., Kauranen, I., \& Barbara, I. (2013). A New Model of Strategic Thinking Competency. Journal of Strategy and Management, 6(3), 242-264.

Obeidat, O., Al-Suradi, M., \& Tarhini, A. (2016). The Impact of Knowledge Management on Innovation: An Empirical Study on Jordanian Consultancy Firms. Management Research Review, 39(10), 1214-1238.

Obeidat, O., El-Rimawi, S., Maqableh, M., \& Al-Jarrah, I. (2013). Evaluating the Profitability of the Islamic Banks in Jordan. European Journal of Economics, Finance and Administrative Sciences, 56, 27-36.

Obeidat, O., Hadidi, A., \& Tarhini, A. (2017). Factors Affecting Strategy Implementation: A Case Study of Pharmaceutical Companies in the Middle East. Review of International Business and Strategy, 27(3), 386-408.

Obeidat, O., Tarhini, A., \& Aqqad, N. (2019). The Relationship among Emotional Intelligence, Conflict Management Styles, and Job Performance in Jordanian Banks. International Journal of Human Resources Development and Management, Forthcoming.

Pinar, M., \& Girard, T. (2008). Investigating the Impact of Organizational Excellence and Leadership on Achieving Business Performance: An Exploratory Study of Turkish Firms. SAM Advanced Management Journal, 73(1), 29-45.

Qawasmeh, F., \& Darqal, N. (2013). The Role of Organization Culture in Achieving Organizational Excellence: Jadara University as a Case Study. International Journal of Economics and Management Sciences, 2(7), 5-19.

Rahman, A., Shahzad, N., Mustafa, K., Khan, M., \& Qurashi, F. (2015). Effects of Organizational Justice on Organizational Commitment. International Journal of Economics and Financial Issues, 6(3), 188-196.

Shannak, R., \& Obeidat, B. (2012). Culture and the Implementation Process of Strategic Decisions in Jordan. Journal of Management Research, 4 (4), pp. 257-281.

Spreitzer, G.M. (2007).Taking Stock: A Review of more than Twenty Years of Research on Empowerment at Work. In C. Cooper and J. Barling (Eds.), Handbook of Organizational 
Strategic Leadership Competencies and its Impact ....

Behavior (pp.54-73). Available online:

www.webuser.bus.umich.edu/spreitze/empowerment.

Stiles, P., \& Trevor, J. (2006). Best Practice and Key Themes in Global Human Resource Management: Project Report. Retrieved from:

http://www.cihrm.jbs.cam.ac.uk/research/downloads/ghrra_report.pdf

Tarhini, A., Alalwan, A., Al-Qirim, N., \& Algharabat, R. (2018). An Analysis of the Factors Influencing the Adoption of Online Shopping. International Journal of Technology Diffusion (IJTD), 9(3), 68-87.

Tarhini, A., Al-Badi, A., Almajali, M., \& Alrabayaah, S. (2017a). Factors Influencing Employees' Intention to Use Cloud Computing. Journal of Management and Strategy, 8(2), 47.

Tarhini, A., Al-Busaidi, K., Bany Mohammed, A., \& Maqableh, M. (2017b). Factors Influencing Students' Adoption of E-Learning: A Structural Equation Modeling Approach. Journal of International Education in Business, 10(2), 164-182.

Tarhini, A., Bany Mohammed, A., \& Maqableh, M. (2016). Modeling Factors Affecting Student's Usage Behaviour of E-Learning Systems in Lebanon. International Journal of Business and Management, 11(2), 299.

Tarhini, A., Mgbemena, C., \& Trab, MSA. (2015). User Adoption of Online Banking in Nigeria: A Qualitative Study. Journal of Internet Banking and Commerce, 20(3), 1-8.

Torset, C. (2001). Strategic Thinking: Why, What and How? An Organizational Model of Strategic Thinking .www, dauphine.fr.

Tutuncu, O., \& Kucukusta, D. (2007). Relationship between Organizational Commitment and EFQM Business Excellence Model: A Study on Turkish Quality Award Winners. Total Quality Managemnet \& Business Exellence, 18(10), 1083-1096.

Verle, K., Markič, M., Kodrič, B., \& Zoran, A. (2014). Managerial Competencies and Organizational Structures. Industrial Management \& Data Systems, 114 (6), 922-935.

Wright, P., Geroy, G., \& Macphee, M. (2000). A Human Resource Model for Excellence in Global Organization Performance. Management Decision, 38(1), 36-42.

Yassien, E., \& Mufleh, M. (2017). The Impact of ERP System's Usability on Enterprise Resource Planning Project Implementation Success via the Mediating Role of User Satisfaction. Journal of Management Research, 9(3), 49-71. 